DOI: $10.5800 /$ GT-2021-12-2-0521

\title{
DEEP CRUSTAL STRUCTURE IN NORTHEASTERN EURASIA AND ITS CONTINENTAL MARGINS
}

\author{
S.N. Kashubin ${ }^{\otimes}$, O.V. Petrov, S.P. Shokalsky, E.D. Milshtein, E.A. Androsov, \\ I.Yu. Vinokurov, O.A. Tarasova
}

Karpinsky Russian Geological Research Institute, 74 Sredny Ave, Saint Petersburg, 199106, Russia

ABSTRACT. The paper reports on the deep geophysical studies performed by the Geological Survey of Russia (VSEGEI) under the international project - Deep Processes and Metallogeny of Northern, Central and Eastern Asia. A model of the deep crustal structure is represented by a set of crustal thickness maps and a 5400-km long geotransect across the major tectonic areas of Northeastern Eurasia. An area of $50000000 \mathrm{~km}^{2}$ is digitally mapped in the uniform projection. The maps show the Moho depths, thicknesses of the main crustal units (i.e. the sedimentary cover and the consolidated crust), anomalous gravity and magnetic fields (in a schematic zoning map of the study area), and types of the crust. The geotransect gives the vertical section of the crust and upper mantle at the passive margin of the Eurasian continent (including submarine uplifts and shelf areas of the Arctic Ocean) and the active eastern continental margin, as well as an area of the Pacific plate.

KEYWORDS: gravity anomaly; deep seismic sounding; Moho boundary; sedimentary cover; consolidated crust; oceanic; transitional; continental crust; continent-ocean transition zone; geotransect

\section{RESEARCH ARTICLE}

Correspondence: Sergey N. Kashubin, Sergey_Kashubin@vsegei.ru
Received: May 30, 2020

Revised: July 8, 2020 Accepted: September 14, 2020

FOR CITATION: Kashubin S.N., Petrov O.V., Shokalsky S.P., Milshtein E.D., Androsov E.A., Vinokurov I.Yu., Tarasova 0.A., 2021. Deep crustal structure in Northeastern Eurasia and its continental margins. Geodynamics \& Tectonophysics 12 (2), 199-224. doi:10.5800/GT-2021$12-2-0521$ 


\title{
ГЛУБИННОЕ СТРОЕНИЕ ЗЕМНОЙ КОРЫ СЕВЕРО-ВОСТОЧНОЙ ЕВРАЗИИ И ЕЕ КОНТИНЕНТАЛЬНЫХ ОКРАИН
}

\author{
С.Н. Кашубин, О.В. Петров, С.П. Шокальский , Е.Д. Мильштейн, Е.А. Андросов, \\ И.Ю. Винокуров, О.А. Тарасова
}

Всероссийский научно-исследовательский геологический институт им. А.П. Карпинского, 199106, СанктПетербург, пр-т Средний, 74, Россия

АНнотАция. В работе представлены результаты обобщения и интерпретации глубинных геофизических исследований, выполненных Геологической службой России (ВСЕГЕИ) в рамках международного проекта «Глубинные процессы и металлогения Северной, Центральной и Восточной Азии». Модель глубинного строения земной коры представлена комплектом карт, отражающих мощностные параметры земной коры, и геотрансектом протяженностью 5400 км, пересекающим основные тектонические области Северо-Восточной Евразии. Комплект цифровых карт, охватывающих область в 50 млн км², создан в единой проекции и включает карты глубины залегания поверхности Мохоровичича, мощности основных подразделений земной коры (осадочный чехол и консолидированная земная кора), аномального поля силы тяжести и аномального магнитного поля, использованных для районирования территории, а также карту типов земной коры. Геотрансект пересекает северовосточную часть Евразии и характеризует вертикальный срез земной коры и верхней мантии пассивной окраины Евразийского континента (включая глубоководные поднятия Северного Ледовитого океана и его шельфовую часть), активную восточную континентальную окраину и выходит в область Тихоокеанской плиты.

КЛЮЧЕВЫЕ СЛОВА: аномалия силы тяжести; глубинное сейсмическое зондирование; поверхность Мохоровичича; осадочный чехол; консолидированная земная кора; океаническая, переходная, континентальная земная кора; область перехода континент - океан; геотрансект

\section{1. ВВЕДЕНИЕ}

Значение информации о строении земной коры и верхней мантии существенно возрастает по мере развития технологий геологического 3D картографирования [Petrov et al., 2016c; Kashubin et al., 2016а; и др.]. Эта информация становится все более востребованной при решении фундаментальных проблем, связанных с развитием геотектонических моделей, определяющих понимание процессов формирования и минерагенической специализации крупных геологических провинций.

В настоящее время практически вся территория Евразии в той или иной мере охвачена глубинными сейсмическими исследованиями [Kashubin et al., 2018c]. Общими элементами глубинного строения, выделяемыми на геолого-геофизических профилях, являются: (1) глубина залегания границы Мохоровичича (граница М, отождествляемая с подошвой земной коры); (2) подошва осадочного слоя или поверхность фундамента (в зависимости от особенностей геологического строения регионов поверхность, отождествляемая или с кровлей консолидированной (осадочной метаморфизованной) коры, или с кровлей кристаллической (верхней) земной коры); (3) граница между верхней и нижней кристаллической корой (между «гранитогнейсовым» и «базальтовым» слоями). Наиболее надежно определяется положение границы М (по записям закритических отраженных РмР и преломленных Рg волн и значениям скоростей $\mathrm{Vp}>7.8-8.0$ км/с ниже этой границы) и подошва осадочного слоя (по характерной смене волновой картины на временных разрезах
MOB-ОГТ и скачку скоростей Vр от значений меньше $3.5-4.5$ км/с до 5.5 км/с и выше).

К настоящему времени на территории Северо-Восточной Евразии сложились предпосылки для обобщения информации о ее глубинном строении в виде комплекта карт и опорных геолого-геофизических разрезов, отражающих строение недр на всю мощность земной коры. В статье приводятся результаты такого обобщения ретроспективных и современных исследований, выполненных преимущественно российскими исследователями в рамках международного проекта «Глубинные процессы и металлогения Северной, Центральной и Восточной Азии» [Petrov et al., 2016a].

\section{2. КАРТЫ АНОМАЛЬНОГО ГРАВИТАЦИОННОГО И МАГНИТНОГО ПОЛЕЙ. РАЙОНИРОВАНИЕ ТЕРРИТОРИИ ПО ХАРАКТЕРУ АНОМАЛЬНЫХ ПОТЕНЦИАЛЬНЫХ ПОЛЕЙ}

Карты аномального гравитационного и аномального магнитного полей созданы на основе компиляции и увязки цифровых массивов, представленных участниками проекта, и данных, находящихся в открытом доступе. Базовыми являлись массивы данных ГИС-Атласа геологических карт России, стран СНГ и сопредельных государств масштаба 1:2500000 [Petrov, 2008]. Для северных широт (от 70) использованы цифровые данные CAMP-M, CAMP-GM [Gaina et al., 2011]. Для расширения карт в области восточных окраинных морей и Тихого океана, а также общей увязки цифровых массивов использованы данные двух мировых карт EMAG2 [Maus et al., 2009] и EGM2008 [Pavlis et al., 2012]. 
Карта аномального магнитного поля создана на основе компиляции вышеуказанных карт и оригинальных цифровых массивов по территории Китая, Кореи и Монголии, представленных участниками проекта (табл. 1).

Создание карт проводилось в несколько этапов. На первом этапе по системе перекрытий были увязаны карты, имеющие существенную общность территорий (территория России и стран СНГ, северные широты от 70 и EMAG2). В качестве базового уровня принята Карта аномального магнитного поля $(\Delta \mathrm{T})$ а России, стран СНГ и прилегающих акваторий [Petrov, 2008]. Увязка уровней карт проводилась по областям, где отсутствуют интенсивные магнитные аномалии. Цифровые массивы карт аномального магнитного поля, представленные геологическими службами Республики Корея, Китайской Народной Республики и Монголии, приведены к выбранному уровню с использованием перекрытий с EMAG2.

В итоге была сформирована карта аномального магнитного поля Северо-Восточной Евразии в едином уровне с размером сетки $5 \times 5$ км (рис. 1$)$.

Гравиметрическая карта создана в редукции Буге с плотностью промежуточного слоя 2.67 г/ $\mathrm{cm}^{3}$ на основе компиляции трех цифровых гравиметрических карт (табл. 2). Данные по области морей Северного Ледовитого океана и EGM2008 приведены к уровню нормального поля, рассчитанного по формуле Гельмерта (1901) $\gamma=9.78030 \times(1+0.005302 \times \sin 2 \varphi-0.000007 \times \sin 22 \varphi)-14$, мГал, где $\gamma$ - нормальное поле, $\varphi$ - широта пункта наблюдения. ArcGP и данные по территории России увязаны между собой по береговой линии.

Гравиметрические карты приведены к единому уровню и увязаны между собой в зонах перекрытия, при этом предпочтение отдавалось более детальным картам, построенным по наземным или набортным исходным данным. Среднеквадратичное отклонение в зонах перекрытия составило \pm 5 мГал (без учета аномальных отклонений).

В результате получена единая гравиметрическая карта на всю площадь проекта с сеткой цифровой матрицы $5 \times 5$ км (рис. 2).

Анализ карт аномалий силы тяжести и аномалий магнитного поля позволил провести районирование территории с выделением и оконтуриванием структур различного ранга. Одним из основных принципов районирования являлось выделение структур на уровне кровли кристаллической коры; в связи с этим их границы могут не совпадать с геологическими границами, картируемыми на поверхности.

Основой районирования являлся комплексный анализ, включающий широкий спектр трансформант: пересчеты поля вверх, расчеты региональных и локальных составляющих, TILT преобразования [Millera, Singh, 1994], различные классификации, а также комплект карт глубинного строения (мощность консолидированной земной коры и осадочного чехла).

В основу районирования положены принципы тектонического районирования, предложенные Ю.А. Косыгиным [Kosygin, 1975]. Согласно этим принципам, районирование рассматривалось как совокупность методов разграничения пространства (в том числе в 3D варианте) в соответствии с выбранной систематикой тел (ранговостью), при соблюдении правил полного без остатка деления этого пространства, без пересечения границ и индивидуальности характеристик выделяемых элементов [Voronin, 2007].

Районирование предусматривало выделение трехранговой системы: аномальная провинция, аномальная область и аномальный район (в порядке убывания).

Таблица 1. Основные картографические материалы, использованные при построении карты аномального магнитного поля Северо-Восточной Евразии

Table 1. Main maps used to construct the map showing the anomalous magnetic field of Northeastern Eurasia

\begin{tabular}{|c|c|c|c|c|}
\hline Территория & Карты & Проекция & Сеть & Год \\
\hline Россия, страны СНГ & Карта аномального магнитного поля & Krasovsky 1940 Equidistant Conic & $2.5 \times 2.5 \mathrm{км}$ & 2008 \\
\hline Севернее $70^{\circ}$ с.ш. & CAMP-M & Stereographic North Pole & $2 \times 2$ км & 2009 \\
\hline EMAG2 & Earth Magnetic Anomaly Grid & WGS 1984 & $2^{\prime} \times 2^{\prime}$ & 2009 \\
\hline Корея & Magnetic anomaly map of Korea & WGS 1984 & $2^{\prime} \times 2^{\prime}$ & 2013 \\
\hline Китай & Aeromagnetic anomaly map of China & Belge Lambert 2005 & $5 \times 5$ км & 2016 \\
\hline Монголия & Mongolia Aeromagnetic Mapping Project & Lambert Conical & $1 \times 1$ км & 2018 \\
\hline
\end{tabular}

Таблица 2. Основные картографические материалы, использованные при построении гравиметрической карты СевероВосточной Евразии

Table 2. Main maps used to construct the gravity map of Northeastern Eurasia

\begin{tabular}{llcc}
\hline Карты & \multicolumn{1}{c}{ Проекция } & Сеть & Год \\
\hline Гравиметрическая карта России, стран СНГ & Krasovsky 1940 Equidistant Conic & $2.5 \times 2.5$ км & 2008 \\
и сопредельных государств & WGS 1984 & $2.5^{\prime} \times 2.5^{\prime}$ & 2008 \\
EGM2008 & Stereographic North Pole & $10 \times 10$ км & 2009 \\
ArcGP & & $10 \times$ \\
\hline
\end{tabular}


При оконтуривании таксонов различных порядков основное внимание уделялось сочетанию морфоструктурных особенностей потенциальных полей и в меньшей степени - знаку и интенсивности аномалий. Выделенные таксоны отражают особенности строения крупных тектонических структур: аномальные провинции - континентов и океанов; аномальные области - платформ, океанических бассейнов, крупных складчатых областей; аномальные районы - крупных блоков. Помимо этого, были выделены линейные структуры, отвечающие зонам сочленения таксонов соответствующего порядка.

Выделение таксонов I порядка (аномальная провинция) и II порядка (аномальная область) в значительной степени опиралось на оценку характера изменения и средние значения мощности земной коры. Основным критерием для выделения аномальных районов являлись морфоструктурные особенности полей, включая характер внутренней зональности.

При оконтуривании таксонов существенная роль отводилась трансформантам поля силы тяжести и аномального магнитного поля, в частности TILT преобразованию.

В результате была составлена карта районирования потенциальных полей Северо-Восточной Евразии (рис. 3; табл. 3).

\section{3. КОМПЛЕКТ КАРТ ГЛУБИННОГО СТРОЕНИЯ}

Глубина залегания поверхности Мохоровичича (M) играет важную роль при изучении глубинного строения Земли. При сейсмологических и глобальных геофизических построениях знание данного параметра необходимо для расчета соответствующих поправок, а при геологической интерпретации он является базовым

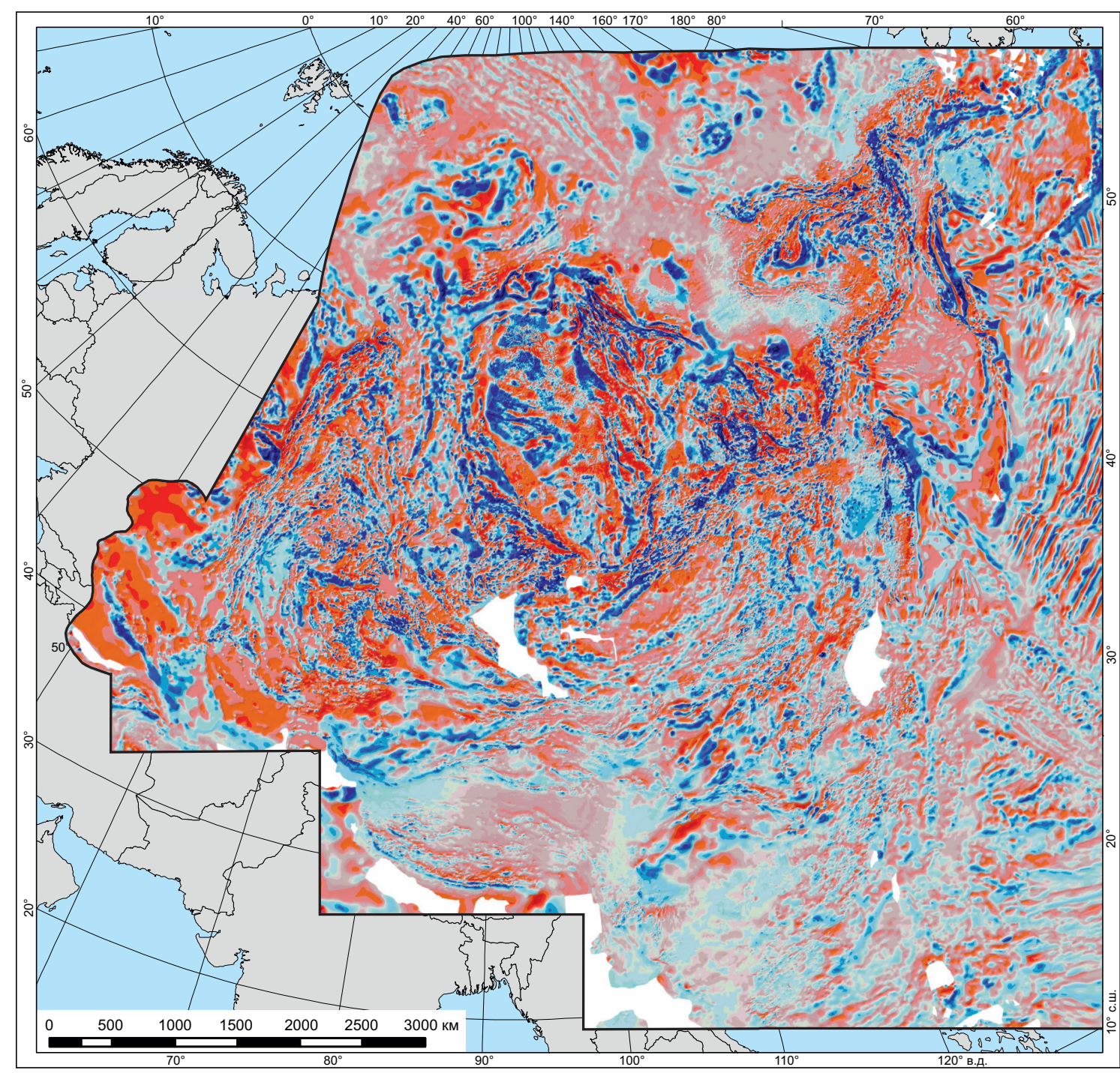

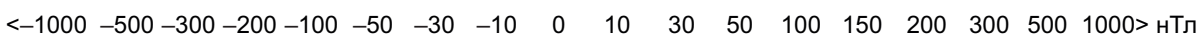

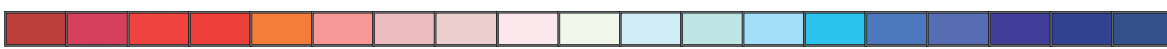

Рис. 1. Карта аномального магнитного поля Северо-Восточной Евразии (белые площади - отсутствие данных).

Fig. 1. Northeastern Eurasia map showing the anomalous magnetic field (white areas - no data). 
элементом как для структурных, так и для геодинамических построений. Глубина залегания поверхности М используется для определения мощности земной коры: на суше - вводится поправка за высоту рельефа, на акваториях - за глубину моря. Изменение мощности коры в совокупности со скоростными параметрами служит основным критерием для выделения континентального и океанического типа земной коры при изучении областей перехода от континентов к океанам.

Мощность земной коры определяется, прежде всего, сейсмическими методами. Общепризнана методика глубинных сейсмических зондирований (ГСЗ), когда подошва земной коры отождествляется с границей Мохоровичича (М), рассчитанной по данным преломленных и закритических отраженных волн [Mooney, 2007]. Иногда подошва земной коры выделяется на сейсмических разрезах, полученных методом отраженных волн (МОВ-ОГТ) [Erinchek, 2007], и по методике обменных волн удаленных землетрясений (MOB3) [Zolotov et al., 1998]. При отсутствии сейсмических данных мощность земной коры оценивается с помощью корреляционных соотношений между глубиной залегания поверхности М, топографией и аномалиями Буге [Demenitskaya, 1975; Kunin et al., 1987].

По мере развития сети глубинных геолого-геофизических профилей начиная с 1990-х годов целым рядом исследователей предпринимались попытки обобщения информации о глубинах залегания подошвы земной коры и основных границах раздела в ее пределах путем построения соответствующих карт на отдельные регионы [Reference Geological and Geophysical Profiles..., 2013; Druzhinin et al., 1990; Morozov et al., 2006;

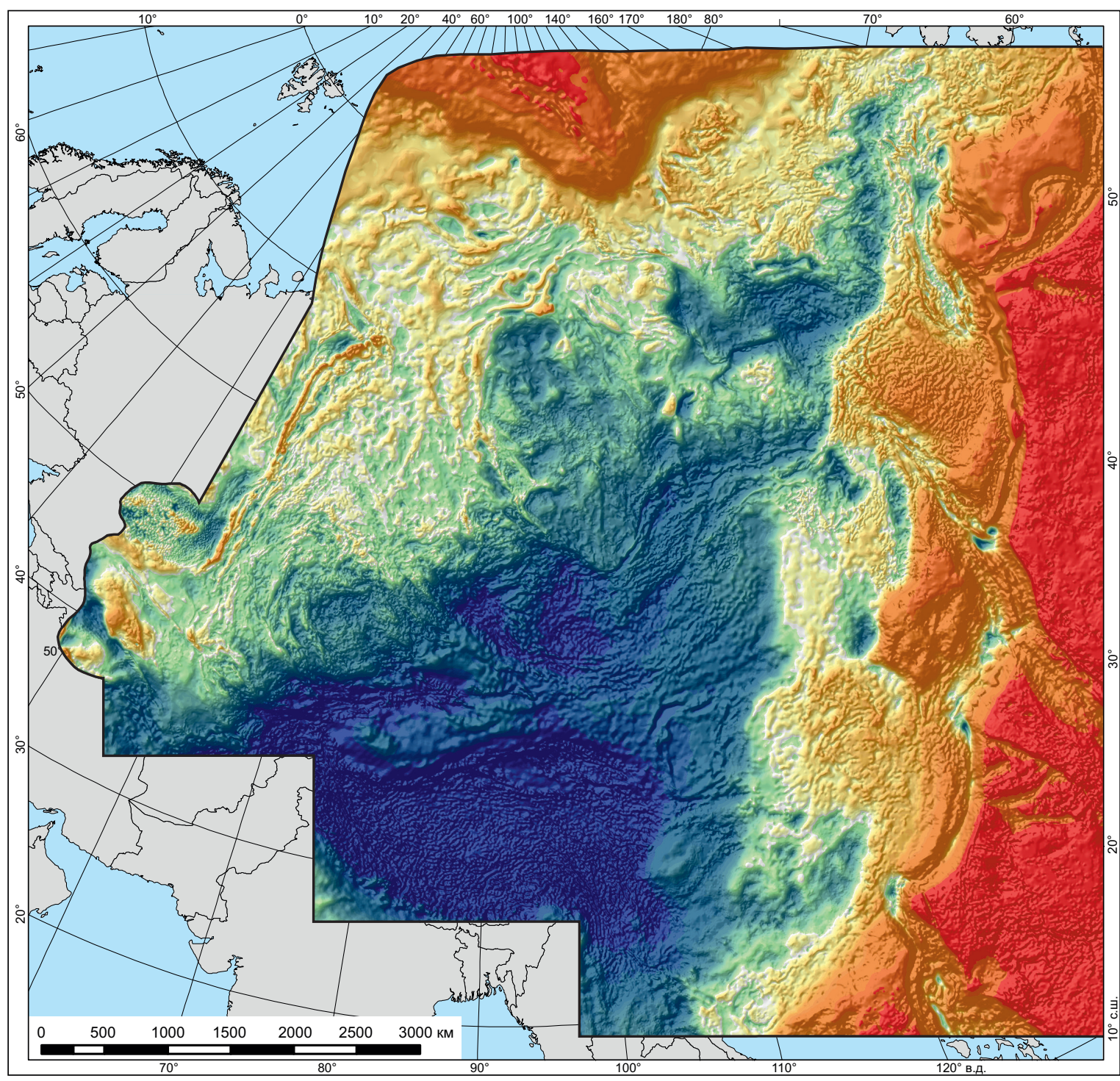

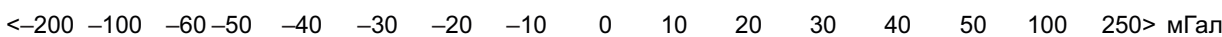

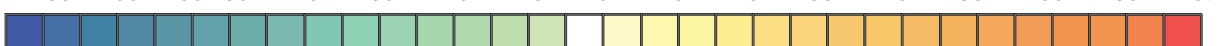

Рис. 2. Гравиметрическая карта Северо-Восточной Евразии (редукция Буге 2.67 г/ см³ $^{3}$ ).

Fig. 2. Northeastern Eurasia map showing the gravity field (Bouguer anomaly map for a density of $2.67 \mathrm{~g} / \mathrm{cm}^{3}$ ). 
Kostyuchenko, Morozov, 2007; Erinchek, 2007; Grad et al., 2009; и др.]. Большинство этих построений не утратили своей актуальности и поныне. Однако в связи с постоянным наращиванием информации о глубинном строении существует необходимость актуализации этих карт и унификации методик их построения.

Карта, представленная на рис. 4, построена по методике, подробно изложенной в работах [Kashubin et al., 2011a, 2014]. Сначала значения глубины до границы М, снятые с сейсмических разрезов с шагом 25 км, были вынесены на карту фактического материала. Затем для заполнения значениями глубин до границы М межпрофильного пространства и обширных территорий, где сейсмические данные полностью отсутствуют, использовались цифровые карты аномального поля силы тяжести, рельефа дневной поверхности и глубин дна океана. По осредненным в радиусе 100 км значениям аномалий Буге и отметкам рельефа по формулам, приведенным в работах [Kashubin et al., 2011a, 2014], рассчитывались глубины Zм отдельно для континентальной и морской части территории с последующей увязкой изолиний в области их сочленения.

Погрешность интерполяции при пересчете значений глубин Zм в равномерный шаг оценивалась путем сравнения интерполированных и исходных значений по точкам, где значения глубин выносились

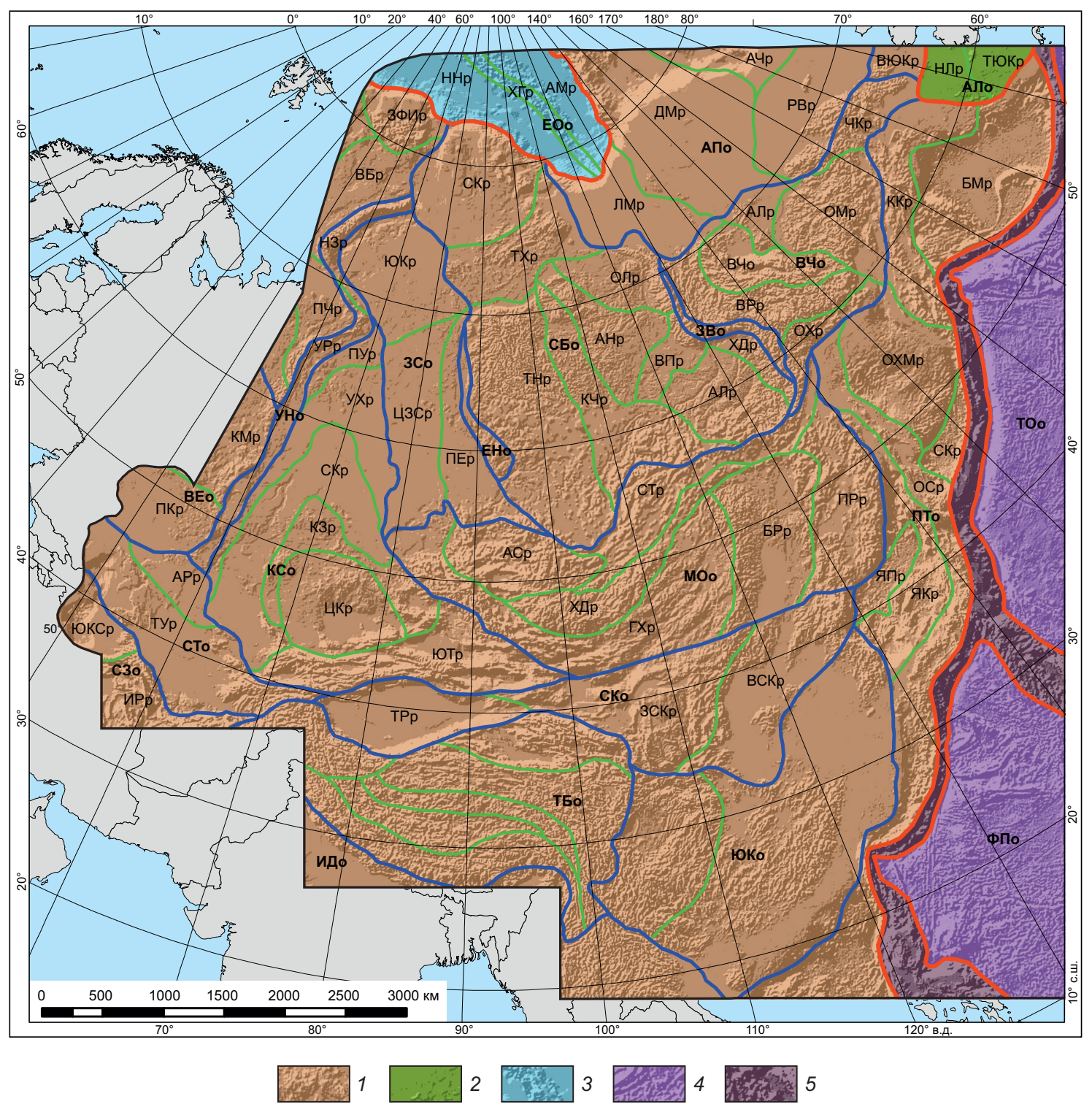

Рис. 3. Схема районирования Северо-Восточной Евразии по характеру потенциальных полей.

Цветом обозначены провинции: 1 - Евразийская, 2 - Северо-Американская, 3 - срединно-океанических хребтов, 4 - Тихоокеанская, 5 - зоны субдукции. Красные линии - границы провинций, синие линии - границы областей, зеленые линии границы районов.

Fig. 3. Schematic zoning of Northeastern Eurasia by potential fields.

Provinces: 1 - Eurasian, 2 - North American, 3 - mid-oceanic ridges, 4 - Pacific, 5 - subduction zones. Boundaries (lines): red - province, blue - area, green - region. 
Таблица 3. Соответствие буквенных обозначений на схеме районирования выделенным таксонам

Table 3. Zone indexes and corresponding names on the schematic zoning map

\begin{tabular}{|c|c|c|c|}
\hline $\begin{array}{l}\text { Обозначение } \\
\text { на схеме }\end{array}$ & $\begin{array}{l}\text { Районирование потенциальных полей } \\
\text { (названия таксонов) }\end{array}$ & $\begin{array}{l}\text { Обозначение } \\
\text { на схеме }\end{array}$ & $\begin{array}{l}\text { Районирование потенциальных полей } \\
\text { (названия таксонов) }\end{array}$ \\
\hline \multicolumn{2}{|c|}{ Евразийская провинция } & CTo & Скифско-Туранская область \\
\hline BEo & Восточно-Европейская область & $\mathrm{APp}$ & Аральский район \\
\hline КМр & Кольско-Мезенский район & ТУр & Туранский район \\
\hline ПКр & Прикаспийский район & EHo & Енисейская область \\
\hline БПо & Баренцевоморско-Печорская область & 3Bo & Западно-Верхоянская область \\
\hline ЦБр & Центрально-Баренцевский район & \multicolumn{2}{|c|}{ Евразийская провинция } \\
\hline ВБр & Восточно-Баренцевский район & УНо & Урал-Новоземельская область \\
\hline ЗФИр & Район Земли Франца-Иосифа & УРp & Уральский район \\
\hline TMp & Тиманский район & H3p & Новоземельский район \\
\hline ПЧр & Печорский район & C3o & Средиземноморская область \\
\hline 3Co & Западно-Сибирская область & ИРр & Иранский район \\
\hline ЮКр & Южно-Карский район & ЮКр & Южно-Каспийский район \\
\hline ЦЗСр & Центрально-Западносибирский район & ЦАо & Ценрально-Азиатская область \\
\hline ПЕр & Приенисейский район & ХДр & Хангай-Даурский район \\
\hline СБо & Сибирская область & ПРр & Приморский район \\
\hline СКр & Северо-Карский район & ГХр & Гоби-Хинганский район \\
\hline TXp & Таймыро-Хатангский район & CTp & Становой район \\
\hline THp & Тунгусский район & $\mathrm{ACp}$ & Алтае-Саянский район \\
\hline КЧр & Котуйско-Чонский район & БРр & Буреинский район \\
\hline AHp & Анабарский район & СКо & Северо-Китайская область \\
\hline ОЛр & Оленекский район & ЗСКр & Западный Сино-Корейский район \\
\hline АЛр & Алданский район & ВСКр & Восточный Сино-Корейский район \\
\hline ХДр & Хандыгский район & $\mathrm{TPp}$ & Таримский район \\
\hline ВПр & Вилюйско-Патомский район & ПТо & Притихоокеанская область \\
\hline ВЧо & Верхояно-Чукотская область & ККр & Корякско-Камчатский район \\
\hline BPp & Верхоянский район & OXMp & Охотоморский район \\
\hline oXp & Охотский район & БМр & Беринговоморский район \\
\hline КЛр & Колымский район & OCp & Островной район \\
\hline $\mathrm{OMp}$ & Омолонский район & СКр & Северо-Курильский район \\
\hline ЧКр & Чукотский район & ЯПр & Япономорский район \\
\hline АЛр & Алазейский район & ТБо & Тибетская область \\
\hline чюо & Чукотско-Юконская область & юКо & Южно-Китайская область \\
\hline ВЮКр & Восточно-Юконский район & идо & Индостанская область \\
\hline ЦАо & Центрально-Арктическая область & \multicolumn{2}{|c|}{ Северо-Американская провинция } \\
\hline ЛМр & Лаптевоморский район & АЛо & Аляскинская область \\
\hline ДМр & Район Де-Лонга-Макарова & НЛр & Нест-Лаврентьевский район \\
\hline АЧр & Альфа-Чукотский район & ТюКр & Танана-Юконский район \\
\hline BPp & Врангельский район & \multicolumn{2}{|c|}{ Провинция срединно-океанических хребтов } \\
\hline КСо & Казахстано-Сибирская область & EOo & Евразийская океаническая область \\
\hline уXр & Уват-Хантымансийский район & ХГр & Район Гаккеля \\
\hline ЮТр & Южно-Тянь-Шаньский район & HHp & Район Нансена \\
\hline ЦКр & Центрально-Казахстанский район & AMp & Район Амундсена \\
\hline КЗр & Казахстан, Зайсанский район & \multicolumn{2}{|c|}{ Тихоокеанская провинция } \\
\hline ПУр & Приуральский район & TOo & Тихоокеанская область \\
\hline СКр & Северо-Казахстанский район & ФПо & Филиппинская область \\
\hline
\end{tabular}


по сейсмическим данным. Среднеквадратическое отклонение между интерполированными и исходными значениями не превысило \pm 2 км, в связи с чем сечение между изолиниями на результирующей карте было принято равным 4 км.

Карта мощности осадочного чехла важна как для понимания внутреннего строения земной коры, так и для оценки перспектив нефтегазоносности исследуемой территории.

Под осадочным чехлом принято понимать толщу осадочных слабодислоцированных и обычно неметаморфизованных горных пород, характеризующихся пологим залеганием и составляющих верхнюю часть разреза земной коры. На континентах осадочный чехол залегает на консолидированной коре, а в океанах - на втором океаническом слое. В то же время в некоторых осадочных бассейнах между осадочным чехлом и кристаллическим фундаментом выделяются промежуточные комплексы, представленные слабометаморфизованными и/или в различной степени дислоцированными образованиями. Иногда эти образования включают в осадочный слой, но чаще их рассматривают как образования так называемого промежуточного структурного этажа. Осадочный чехол уверенно определяется на сейсмических разрезах по характеру сейсмической записи и по значениям скоростей упругих волн, поэтому сейсмические методы играют ведущую роль при изучении осадочного чехла. На временных разрезах МОВ-ОГТ подошва осадочного чехла обычно фиксируется резкой сменой протяженных и субгоризонтально ориентированных осей синфазности на штриховое, разноориентированное поле отражателей или

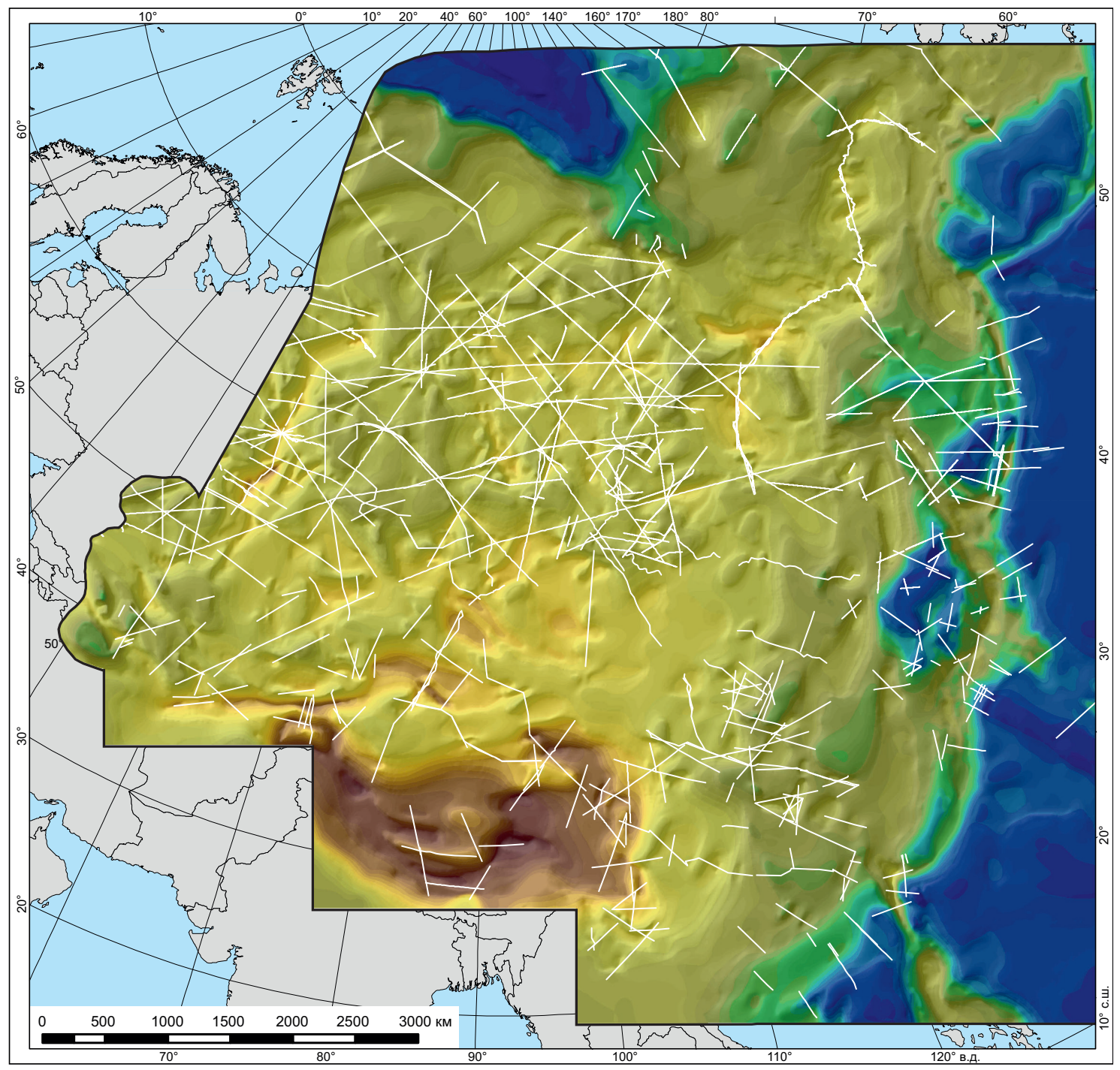

$\begin{array}{llllllllllllllllll}-76 & -72 & -68 & -64 & -60 & -56 & -52 & -48 & -44 & -40 & -36 & -32 & -28 & -24 & -20 & -16 & -12 & \text { км }\end{array}$

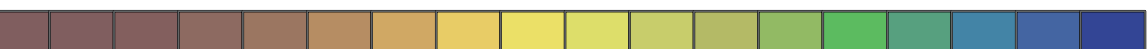

Рис. 4. Глубина залегания поверхности М Северо-Восточной Евразии (белыми линиями показаны основные профили глубинных сейсмических исследований).

Fig. 4. Moho depth map of Northeastern Eurasia (white lines - deep seismic profiles). 
полное прекращение регулярной сейсмической записи. Этот горизонт, индексируемый на разрезах МОВ-ОГТ как АФ (акустический фундамент), обычно совпадает со скоростной границей первого рода, выделяемой при наблюдениях МПВ, ГСЗ и соответствующей, как отмечалось выше, резкому повышению скоростей продольных волн от значений меньше 3.5-4.5 км/с до 5.5 км/с и выше. Как правило, по этим признакам и строится подошва осадочного чехла по сейсмическим данным.

Изученность территории сейсмическими методами крайне неравномерна. Наиболее изученными сейсмическими методами являются Западно-Сибирский и Восточно-Сибирский регионы. Общий объем сейсмических исследований МОВ-ОГТ в пределах нефтегазоносных провинций (в основном на шельфе и в Западной Сибири) превышает сотни тысяч погонных километров, при этом подавляющая часть данных обобщена в виде среднемасштабных структурных карт. В связи с этим для построения карты мощности осадочного чехла нет необходимости использовать первичные сейсмические данные, а достаточно воспользоваться результатами этих предшествующих более детальных построений.

Необходимо отметить, что исследуемая территория в целом обеспечена картографическими материалами для построения карты мощности осадочного чехла в масштабе 1:5000000. Сведения об основных материалах, использованных при построении карты мощности осадочного чехла, приведены в табл. 4.

Создание компиляционной карты потребовало унификации использованных данных и увязки их в областях перекрытия карт. Необходимость унификации связана с тем, что исходные картографические материалы являют собой различные по форме представления информационные массивы: обобщающие карты отражают как мощность осадочного чехла, так и рельеф разновозрастного фундамента. Увязка имеющихся карт в областях их сочленения осуществлялась путем редактирования стыков с учетом характера потенциальных полей. На перекрывающихся участках предпочтение отдавалось более детальной информации. На сводной карте изопахитами с сечением 1 км представлена мощность разновозрастного осадочного чехла (рис. 5).

Карта мощности консолидированной земной коры (рис. 6) была построена как разность между картами мощности земной коры и мощности осадочного чехла.

Типы земной коры Центральной, Северо-Восточной Азии, Дальневосточной и Арктической областей перехода континент - океан. Комплект карт, приведенных на рис. $3,4,5,6$, и опубликованные глубинные геолого-геофизические разрезы по профилям, положение которых показано на рис. 4, отражают основные особенности глубинного строения земной коры и верхней мантии Евразии. На основе этих данных и представлений о типах земной коры, изложенных в работах [Belousov, Pavlenkova, 1989; Mooney, 2007; Kashubin et al., 2013], была составлена схематическая карта типов земной коры Центральной, Северо-Восточной Азии и областей перехода континент - океан (рис. 7) [Kashubin et al., 2018b]. В основе всех этих типизаций земной коры лежат различия океанической и континентальной коры по мощности, внутреннему строению и составу.

По этим параметрам характерными чертами континентальной коры являются: большая мощность (как правило, более 30 км) и наличие в консолидированной части коры мощного (до 10 км и более) верхнего слоя со скоростями продольных волн 5.8-6.4 км/с, часто называемого «гранитогнейсовым» слоем. Океаническая кора, в противовес континентальной, тонкая (как правило, менее 10 км), в ней «гранитогнейсовый» слой отсутствует, и она практически полностью представлена породами со скоростями продольных сейсмических волн более 6.5 км/с. Детальные сейсмические исследования, охватывающие активные и пассивные окраины континентов и океанические поднятия, показали, что, помимо континентальной и океанической коры, часто встречается кора с промежуточными параметрами. Она характеризуется мощностью от 10 до 30 км, и в ней существенно сокращен или полностью отсутствует «гранитогнейсовый» слой. Отнесение этой коры к океаническому или континентальному типу часто неоднозначно, поэтому нередко предлагается определять такую кору как переходную [Belousov, Pavlenkova, 1989; и др.].

Океаническая и континентальная кора весьма существенно различаются по мощности и скоростным характеристикам. Особенно очевидны эти различия на скоростных моделях, построенных по данным многоволновых сейсмических исследований, использующих в качестве дополнительной характеристики среды значения отношения Vp/Vs [Ljones et al., 2004; Breivik et al., 2005; Mjelde et al., 2009; Kashubin et al., 2016b, 2018a]. B кристаллической коре континентов отношение Vp/Vs редко превышает 1.77, в то время как во 2-м и 3-м слоях океанической коры Vp/Vs обычно составляет 1.85-1.90. При этом в осадочном слое и в океанической и в континентальной коре Vp/Vs меняется в широких пределах, в целом превышая значения 1.9-2.0. С учетом связи между суммарным содержанием кремнезема в кристаллических горных породах и отношением Vp/Vs [Aleinikov et al., 1991] эти различия представляются вполне закономерными и свидетельствуют о различной основности океанического и континентального типов земной коры.

В табл. 5 приведены обобщенные данные о моделях строения и скоростных параметрах основных слоев океанической и континентальной земной коры, которые, наряду с данными о мощности различных слоев и мощности коры в целом, служат основой для типизации земной коры. Как можно видеть из приводимой таблицы, отличие континентальной коры от океанической заключается в том, что в последней отсутствует верхняя и средняя кора. Это наиболее надежно фиксируется по различиям в значениях отношения Vp/Vs.

В качестве типовых колонок земной коры для блоков, показанных на схематической карте типов земной коры (рис. 7), приводятся фактические колонки, 
Таблица 4. Основные картографические материалы, использованные при построении карты мощности осадочного чехла Северо-Восточной Евразии

Table 4. Main maps used to construct the Northeastern Eurasia map showing the thicknesses of the sedimentary cover

\begin{tabular}{|c|c|c|c|c|c|}
\hline № & Год & Автор (редактор) & № & Год & Автор (редактор) \\
\hline 1 & 1981 & Сурков В.С. и др. & 13 & 2005 & Ким Б.И. и др. \\
\hline 2 & 1982 & Семенович В.В. и др. & 14 & 2006 & Корень Т.Н. и др. \\
\hline 3 & 1986 & Красный Л.И. и др. & 15 & 2007 & Сурков В.С. и др. \\
\hline 4 & 1988 & Костюченко С.Л. и др. & 16 & 2008 & Ларичев А.И. и др. \\
\hline 5 & 1988 & Богданов Н.А. и др. & 17 & 2009 & Сурков В.С. и др. \\
\hline 6 & 1999 & Эринчек Ю.М. и др. & 18 & 2009 & Divins D.L. et al. \\
\hline 7 & 2000 & Костюченко С.Л. и др. & 19 & 2009 & Grantz A. et al. \\
\hline 8 & 2001 & Gramberg I.S. et al. & 20 & 2010 & Laske G. et al. \\
\hline 9 & 2001 & Парфенов Л.М. и др. & 21 & 2010 & Шокальский С.П. и др. \\
\hline 10 & 2002 & Эринчек Ю.М. и др. & 22 & 2011 & Сакулина Т.С. и др. \\
\hline 11 & 2004 & Грамберг И.С. и др. & 23 & 2011 & Поселов В.А. и др. \\
\hline 12 & 2004 & Веселов О.В. и др. & 24 & 2016 & Petrov O.V. et al. \\
\hline
\end{tabular}
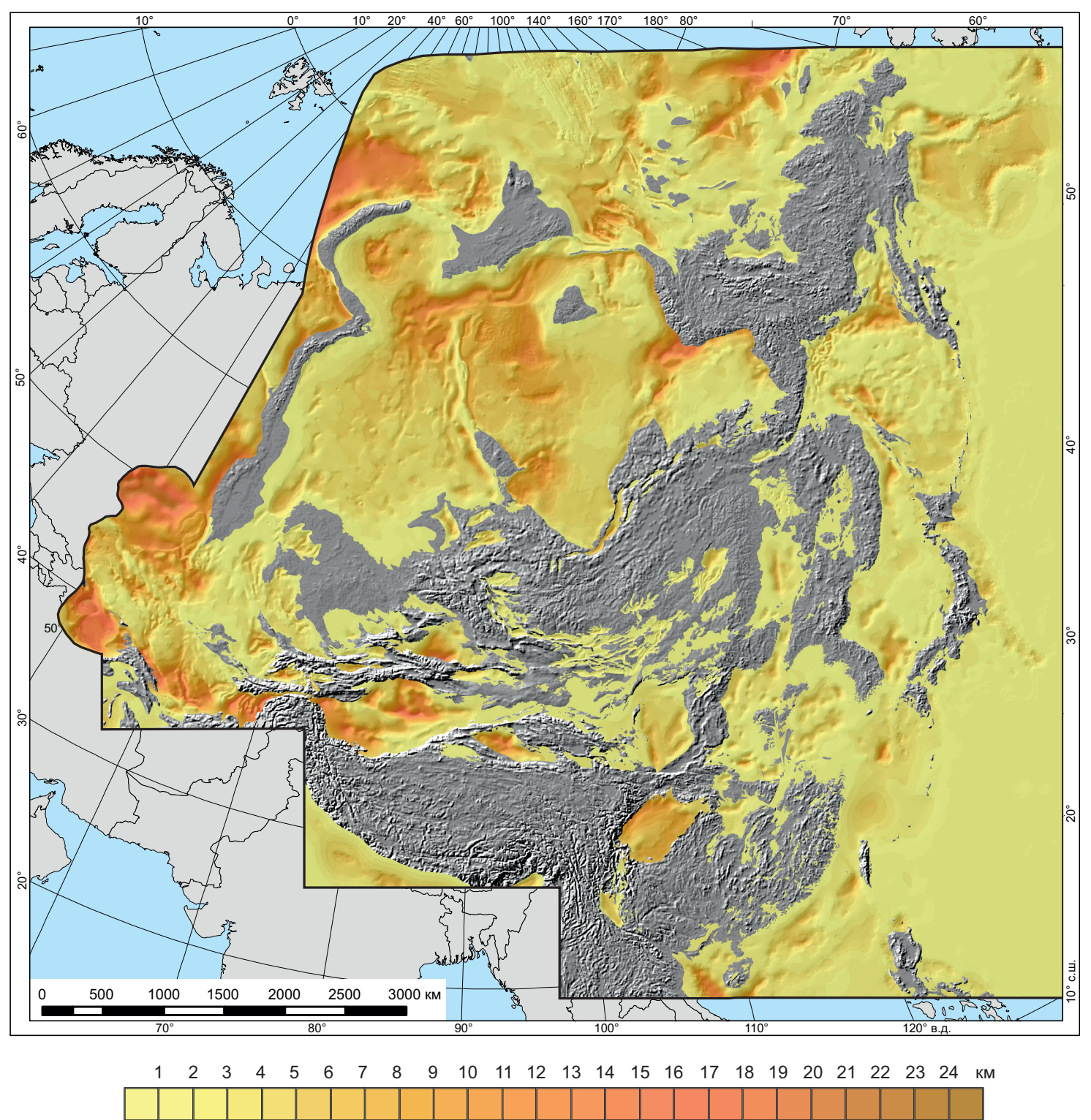

Рис. 5. Мощность осадочного чехла Северо-Восточной Евразии.

Fig. 5. Sedimentary cover thickness map of Northeastern Eurasia. 


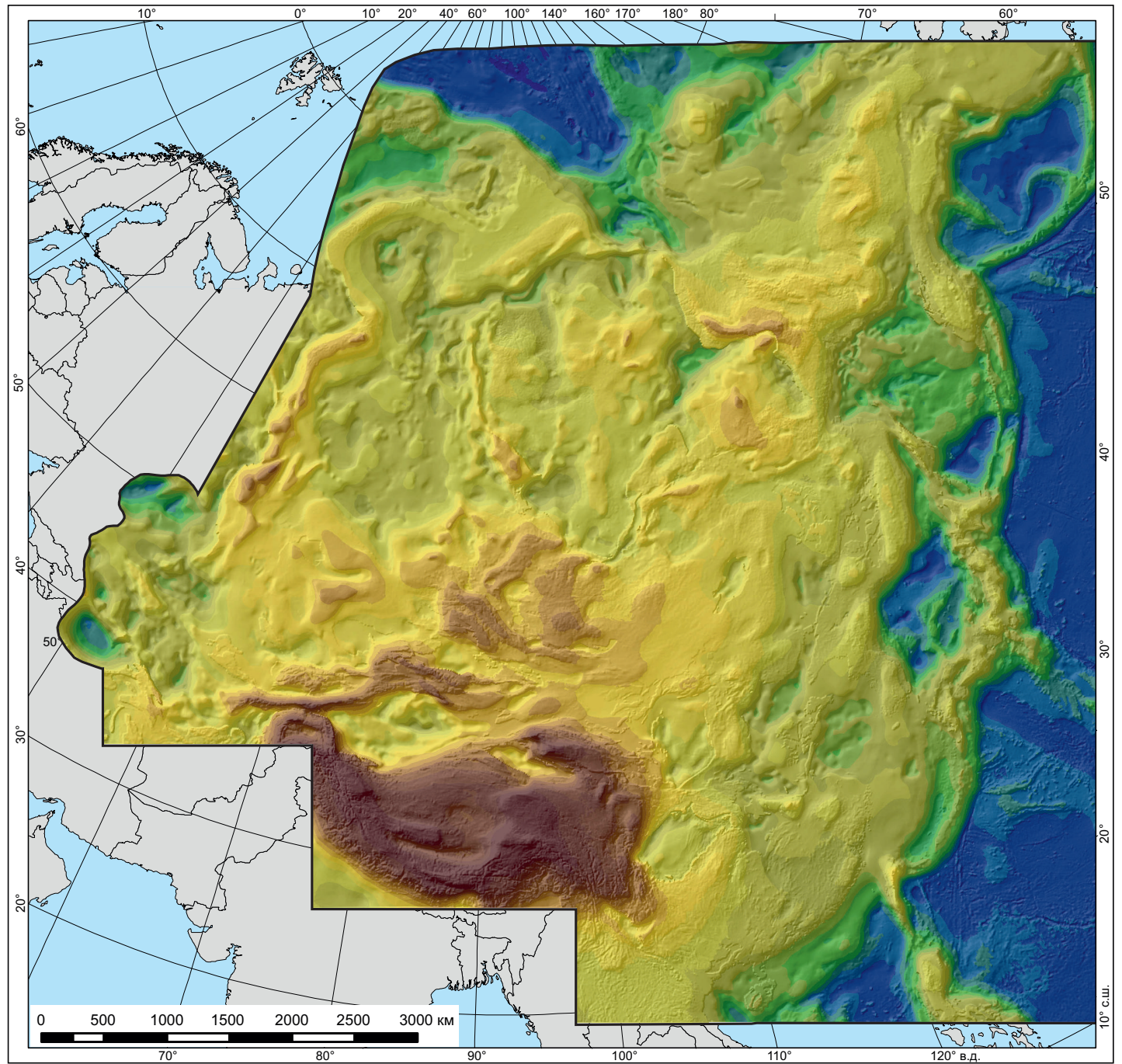

$\begin{array}{llllllllllllllllllll}4 & 8 & 12 & 16 & 20 & 24 & 28 & 32 & 36 & 40 & 44 & 48 & 52 & 56 & 60 & 64 & 68 & 72 & 76 & \text { км }\end{array}$

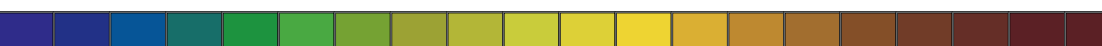

Рис. 6. Мощность консолидированной земной коры Северо-Восточной Евразии.

Fig. 6. Consolidated crust thickness map of Northeastern Eurasia.

Таблица 5. Обобщенные модели строения и скоростные параметры океанической и континентальной земной коры [Каshubin et al., 2013, с уточнениями]

Table 5. Typical sections and velocity parameters of the oceanic and continental crust [Kashubin et al., 2013, updated]

\begin{tabular}{|c|c|c|c|c|}
\hline \multicolumn{2}{|c|}{ Океаническая кора } & \multirow{2}{*}{ Vp, км/с } & \multicolumn{2}{|c|}{ Континентальная кора } \\
\hline Основные слои & $\mathrm{Vp} / \mathrm{Vs}$ & & $\mathrm{Vp} / \mathrm{Vs}$ & Основные слои \\
\hline Вода & - & $1.45-1.50$ & - & Вода \\
\hline Осадки & $2.1-2.5$ & $2.0-4.5$ & $2.1-2.5$ & Осадки \\
\hline 2-й слой океанической коры & $1.8-2.2$ & $4.2-6.0$ & $1.7-2.1$ & $\begin{array}{l}\text { Базальты, переслаивающиеся } \\
\text { с осадками, или складчато- } \\
\text { метаморфический слой }\end{array}$ \\
\hline & & $5.8-6.4$ & $1.69-1.73$ & Верхняя кора \\
\hline & & $6.3-6.7$ & $1.73-1.75$ & Средняя кора \\
\hline 3-й слой океанической коры & $1.81-1.87$ & $6.6-7.2$ & $1.75-1.77$ & Нижняя кора \\
\hline Коромантийный слой & $1.78-1.84$ & $7.2-7.6$ & $1.78-1.84$ & Коромантийный слой \\
\hline
\end{tabular}


составленные на основе опубликованных сейсмических моделей (табл. 6) в соответствии с обобщенными скоростными параметрами, приведенными в табл. 5. Необходимо отметить, что эта схема, основанная исключительно на геофизических данных, несущих информацию о глубинном строении, в ряде случаев может существенно отличаться от сложившихся геологических и тектонических представлений. Более того, по мнению авторов, приведенные данные могут и должны стимулировать появление различных, в том числе альтернативных, геолого-тектонических построений в данном регионе.

Как можно видеть из рис. 7, земная кора региона весьма разнообразна. Здесь выделяются блоки как с маломощной (менее 5-6 км) практически 2-слойной океанической корой, так и с очень мощной (более 70 км) корой Гималаев и 4-слойной консолидированной корой Урала. На схеме выделены три основных типа земной коры: океанический, переходный и континентальный, каждый из которых, в свою очередь, разделяется на ряд подтипов (см. табл. 6).

Два подтипа океанической коры (подтипы 1 и 2 на рис. 7) различаются, прежде всего, мощностью коры. Тонкая кора (менее 5-6 км) представлена двумя слоями (2-й и 3-й слои океанической коры в табл. 5), перекрытыми маломощными осадками [Iwasaki et al., 2013]. Она распространена в глубоководной части Тихого океана и Евразийском бассейне Северного Ледовитого океана. В районе хребта Бонин в Тихом океане выделяется поднятие, представленное значительно более толстой (свыше 20 км) океанической корой, близкой по своим свойствам к утолщенной коре восточно-тихоокеанских поднятий и океанических плато. При этом увеличение мощности происходит за счет появления в низах коры коромантийного комплекса со скоростями продольных волн 7.4-7.6 км/с [Iwasaki et al., 2013]. Несмотря на значительную мощность и сходство по этому параметру с континентальной корой, земная кора этого поднятия по геологической позиции относится к океаническому типу.

В особый, переходный, тип выделена на карте кора дальневосточной области перехода континент - океан. Она представлена протяженной линейной зоной субдукции (подтип 3 на рис. 7), в которой океаническая кора Тихоокеанской плиты погружается под континентальную окраину Евразии [Nakanishi et al., 2009].

Данные ГСЗ [Iwasaki et al., 2013; Nakanishi et al., 2009] уверенно фиксируют скоростные параметры надсубдукционной зоны с достаточно типичной континентальной корой. Сама зона субдукции обычно выделяется по данным сейсмологии как сейсмофокальная зона с падением порядка $35-45^{\circ}$ в направлении континента. Проекции на дневную поверхность очагов землетрясений в этой зоне, представляющей переход от Тихоокеанской плиты к Евразийскому континенту, образуют полосу шириной 150-200 км при протяженности в несколько тысяч километров [Kanao et al., 2015]. Площадные параметры зоны соответствуют проекции на земную поверхность совмещенных по зоне БеньофаЗаварицкого разрезов континентальной и пододвигаемой под нее океанической коры. Специфика строения и масштабы этого геологического феномена побудили авторов выделить самостоятельный подтип коры зоны субдукции (подтип 3 на рис. 7).

Другим контрастным подтипом коры в этой переходной области континент - океан (подтип 4 на рис. 7) явилась резко утоненная кора глубоководных впадин задуговых бассейнов, отличающаяся уменьшенной мощностью кристаллической коры и увеличенной мощностью осадков от остальной - шельфовой - части окраинноморских бассейнов. Как показали недавние исследования земной коры этого подтипа на примере ЮжноОхотской глубоководной котловины (многоволновые сейсмические исследования с донными станциями на профиле 2ДВ-М в Охотском море), в пределах этой котловины фиксируется тонкая кора, близкая по своим параметрам к верхней континентальной коре [Kashubin et al., 2011b, 2017]. Из-за малой толщины земной коры, и особенно ее верхней сиалической части, и скоростных параметров нижней коры, близких к океаническому типу, такая кора задуговых бассейнов может рассматриваться как «субокеаническая кора». Масштабы ее распространения в переходной области требуют уточнения, поскольку детальные материалы, обосновывающие этот подтип земной коры, имеются пока только для Охотоморского окраинного бассейна.

Континентальная земная кора, охватывающая большую часть изучаемой территории, включает остальные подтипы (подтипы с 5-го по 12-й на рис. 7), объединенные в четыре основные группы.

К первой группе относятся 5 и 6-й подтипы земной коры глубоких осадочных бассейнов. Оба подтипа характеризуются редуцированной земной корой за счет сокращения консолидированной ее части и самым мощным (до 18-20 км) осадочным выполнением (см. рис. 5). Подтипы различаются количеством слоев, выделяемых в кристаллической коре. В 5-й подтип включены осадочные бассейны с «безгранитной» (или «субокеанической») земной корой, такие как Прикаспийская впадина [Volvovsky B.S., Volvovsky I.S., 1988; Pavlenkova et al., 2016; Kostyuchenko et al., 1999].

Остальные глубокие осадочные бассейны, выделяемые на карте (Северо-Баренцевский, Южно-Карский, Северо-Чукотский, Вилюйский и др.), подстилаются 2-слойной кристаллической корой [Pavlenkova et al., 2016; Sakulina et al., 2016; Zverev, Kosminskaya, 1980; Roslov et al., 2009].

В основании большинства бассейнов этой группы, как правило, располагаются рифтогенные структуры.

В верхней части фундамента некоторых бассейнов, залегающих преимущественно в пределах молодых плит (Южно-Карский, Пур-Гыданский, Северо-Чукотский бассейны), обнаруживается складчато-метаморфический слой («переходный комплекс»). В других бассейнах, например в Северо-Баренцевском и Вилюйском, обычно располагающихся в пределах древних платформ 


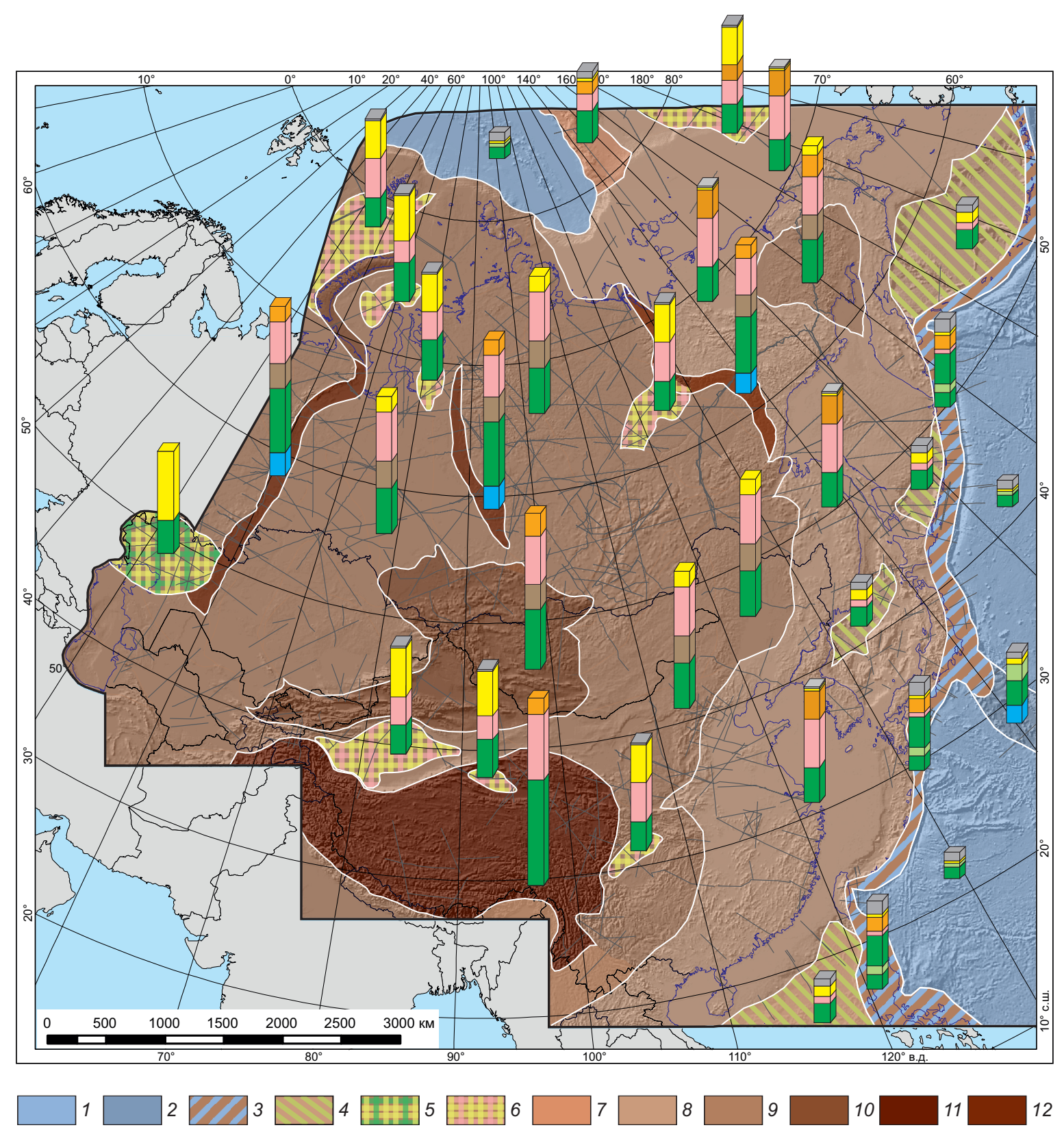

Рис. 7. Схематическая карта типов земной коры Северо-Восточной Евразии [Kashubin et al., 2018b].

1-2 - океаническая земная кора: 1 - океанических бассейнов, 2 - океанических плато; 3-4 - переходная земная кора: 3 - зоны субдукции, 4 - задуговых бассейнов; 5-12 - континентальная земная кора: 5 - кора глубоких осадочных бассейнов (прикаспийский тип, «безгранитный»), 6 - кора глубоких осадочных бассейнов (палеорифтовый тип), 7 - кора подводных хребтов и поднятий, 8 - кора окраинных складчатых областей и шельфовых морей, преимущественно с двухслойной кристаллической корой, 9 - кора кратонов и срединных массивов, преимущественно с трехслойной кристаллической корой, 10 - кора внутриконтинентальных складчатых областей, преимущественно с трехслойной кристаллической корой, 11 - кора складчато-надвиговых областей (гималайский тип), 12 - кора внутриконтинентальных складчатых поясов и пограничных зон, преимущественно с трехслойной кристаллической корой. Серыми линиями показаны профили МПВ, ГСЗ. Типовые колонки земной коры по сейсмическим данным см. в табл. 6 .

Fig. 7. Crustal types of Northeastern Eurasia (schematic map from [Kashubin et al., 2018b]).

1- 2 - oceanic crust: 1 - oceanic basins, 2 - oceanic plateaus; 3-4 - transitional crust: 3 - subduction zones, 4- back-arc basins; 5-12 continental crust: 5 - deep sedimentary basins of the Caspian type (granite-free), 6 - deep sedimentary basins of the paleorift type, 7 underwater ridges and uplifts, 8 - marginal fold areas and shelf seas (mainly, two-layer crystalline crust), 9 - cratons and crystalline massifs (mainly, three-layer crystalline crust), 10 - intracontinental fold areas (mainly, three-layer crystalline crust), 11 - fold-thrust areas of the Himalayan type, 12 - intracontinental fold belts and marginal zones (mainly, three-layer crystalline crust). Grey lines - DSS profiles. Typical crust sections are given in Table 6. 
Таблица 6. Типовые колонки земной коры структур Центральной, Северо-Восточной Азии и областей перехода континент - океан

Table 6. Typical Earth's crust sections of Central, Northeast Asia and continent-ocean transition areas

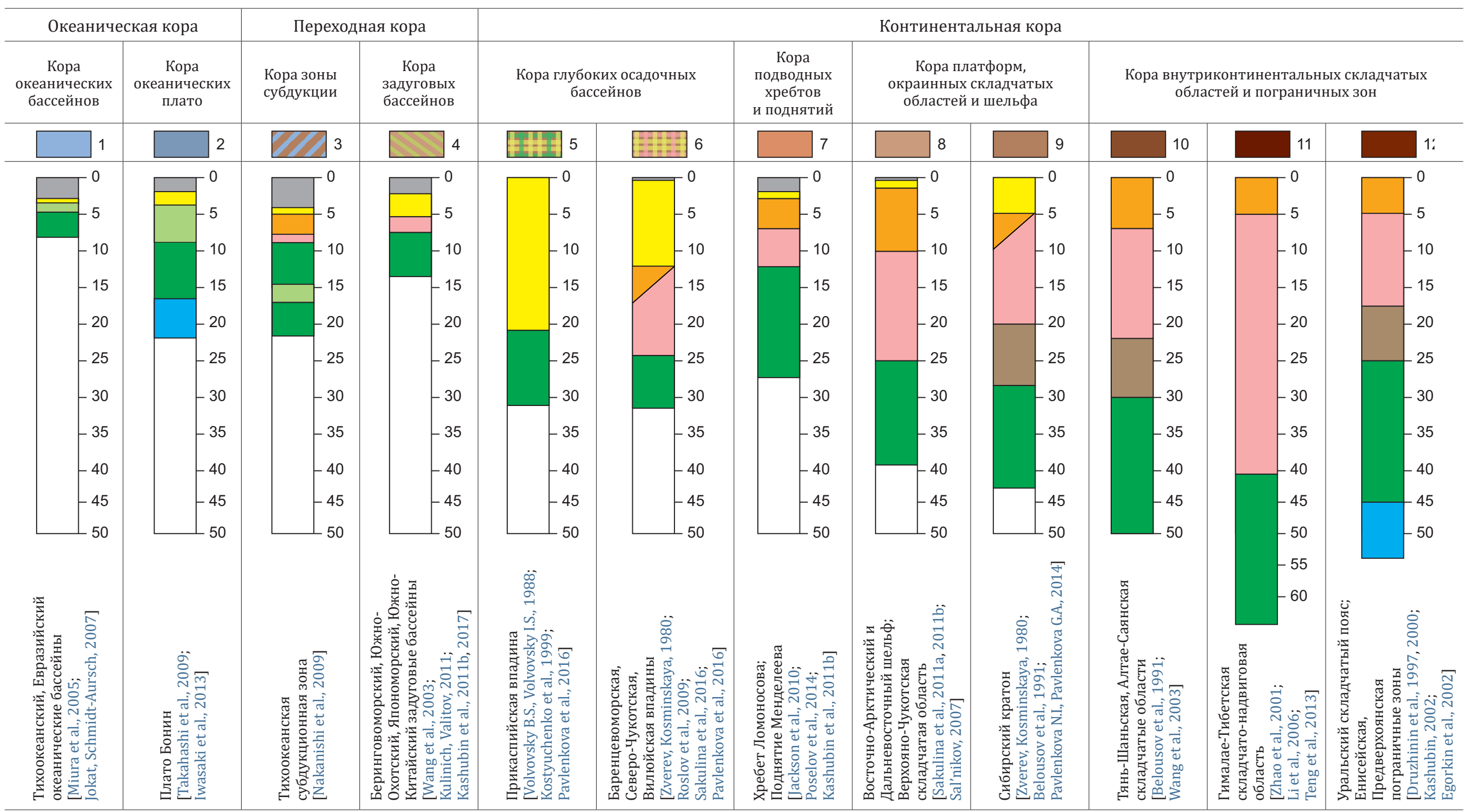

Примечание. Колонки составлены на основе опубликованных сейсмических моделей в соответствии с обобщенными скоростными параметрами, приведенными в табл. 5.

Note. This sections compiled from published seismic models in accordance with the generalized velocity parameters given in Table 5. 
с протерозойским фундаментом, складчатый комплекс может отсутствовать.

Вторая группа на рассматриваемой территории представлена лишь одним подтипом (подтип 7 на рис. 7), соответствующим коре подводных поднятий, сформировавшихся в обстановке рифтовых пассивных континентальных окраин. К таким поднятиям относятся, например, хребет Ломоносова и поднятие Менделеева.

Континентальная природа земной коры хребта Ломоносова признается практически всеми исследователями Арктики [Jackson et al., 2010; Poselov et al., 2014]. В настоящее время хребет Ломоносова рассматривается как смыкание подводных продолжений окраин Евразийского континента и Гренландии в глубоководной части Арктического бассейна.

Земная кора системы поднятий Альфа-Менделеева, исследованная в последнее время по ряду профилей ГС3 [Lebedeva-Ivanova et al., 2006; Poselov et al., 2011; Funck et al., 2011; Kashubin et al., 2016b, 2018a], также соответствует континентальному типу, однако отличается от типичной континентальной коры увеличенной мощностью ее нижней части (по В.В. Белоусову, вследствие «базификации»). Ныне предполагается, что эта особенность глубинного строения вышеупомянутых Центрально-Арктических поднятий обусловлена базитовой переработкой сиалической континентальной коры и, в частности, андерплейтингом, формированием в коре периферических базальтовых очагов и внедрением мафических комплексов в период формирования в этой части Арктики обширной меловой магматической провинции HALIP - High Arctic Large Igneous Province [Morozov et al., 2013; Buchan, Ernst, 2006; Embry, 1991; Estrada et al., 1999; Petrov et al., 2016b].

Третья группа объединяет 8 и 9-й подтипы, характеризующиеся нормальной континентальной корой платформ и обрамляющих их окраинных складчатых областей на суше и шельфе. Они занимают основную часть Северо-Восточной Азии и различаются количеством слоев, выделяемых в кристаллической коре. Так, подтип 8 на рис. 7 представлен Верхояно-Чукотской и Амурской складчатыми областями с прилегающими восточно-арктическим и дальневосточным шельфами. Мощность земной коры для этого подтипа не превышает 35-40 км, а в кристаллической коре, как правило, выделяются верхняя и нижняя кристаллическая кора [Sakulina et al., 2011b; Sal'nikov, 2007]. К подтипу 9 на рис. 7 отнесены Западно-Сибирская плита, Сибирский кратон, Омолонский кратонный блок, Казахстанская складчатая область и другие регионы Центральной и Восточной Азии, земная кора которых характеризуется суммарной мощностью 40-45 км и, как правило, 3-слойным строением.

Четвертая группа характеризует подтипы земной коры протяженных внутриконтинентальных областей (коллизионных складчатых поясов) и пограничных зон с заметно утолщенной корой (подтипы 10-12 на рис. 7). Все три подтипа различаются количеством слоев, выделяемых в кристаллической коре. Подтип 10 объединяет
Тянь-Шаньскую и Алтае-Саянскую складчатые области с 3-слойной (верхняя - средняя - нижняя) кристаллической корой мощностью 50 км и более [Belousov et al., 1991; Wang et al., 2003]. Подтип 11 включает ГималаеТибетскую складчато-надвиговую область с наиболее мощной корой более 70 км [Li et al., 2006].

К подтипу 12 отнесены Уральский складчатый пояс с суммарной мощностью земной коры около 55 км, в пределах которой под 3-слойной кристаллической корой устойчиво выделяется коромантийный слой [Каshubin, 2002; Druzhinin et al., 1997, 2000; и др.], а также Енисейская и Предверхоянская «пограничные зоны», выделяемые вдоль западной и северо-восточной границ Сибирского кратона [Egorkin et al., 2002].

Таким образом, сейсмические исследования в Центральной и Северо-Восточной Азии, а также дальневосточной и арктической областях перехода континент - океан выявили существенную неоднородность структуры земной коры, которая позволяет выделить вполне определенные ее типы и подтипы. Выполненные построения показали закономерное уменьшение суммарной мощности земной коры от центральной части Евразии к ее дальневосточной окраине и далее к Тихому океану. При этом уменьшение мощности консолидированной коры связано с переходом от преимущественно 3-слойной кристаллической коры в центре континента к 2-слойной консолидированной коре на окраине континента и в пределах шельфовых морей.

\section{4. СВОДНЫЙ ГЕОЛОГО-ГЕОФИЗИЧЕСКИЙ ГЕОТРАНСЕКТ}

Одним из элементов изучения глубинного строения крупных блоков литосферы является создание сверхдлинных геотрансектов, отражающих соотношения региональных тектонических структур между собой и позволяющих проиллюстрировать историю геологического развития исследуемого региона. Современный геотрансект является элементом 3D модели глубинного строения литосферы и представляет собой серию геофизических монометодных разрезов земной коры и верхней мантии Земли вдоль выбранной линии и набор интерпретационных моделей, включая геологогеофизическую.

Сводный геотрансект «Северный Ледовитый океан - северо-восток России - Тихий океан», протяженностью 5400 км, пересекает существенно различные тектонические области: арктическую пассивную континентальную окраину, мезозойскую складчатую область, активную континентальную окраину (рис. 8). Он максимально полно обеспечен фактическими глубинными геофизическими наблюдениями и представляет собой непрерывное сочленение четырех опорных геолого-геофизических профилей: Арктика-2005, 5-АР, 2-ДВ, 2-ДВ-М - и их продолжение в Тихоокеанскую океаническую плиту.

Модель геотрансекта представлена серией монометодных геофизических разрезов (сводные сейсмические 
(a)

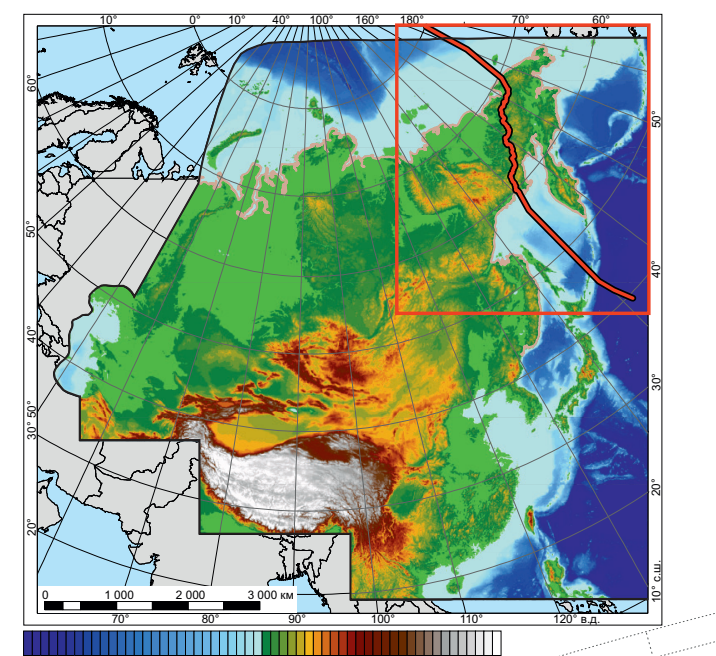

(в)

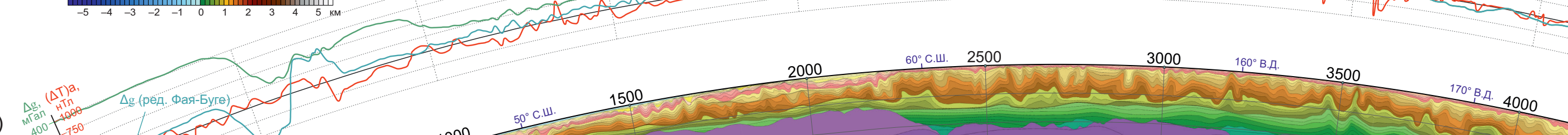

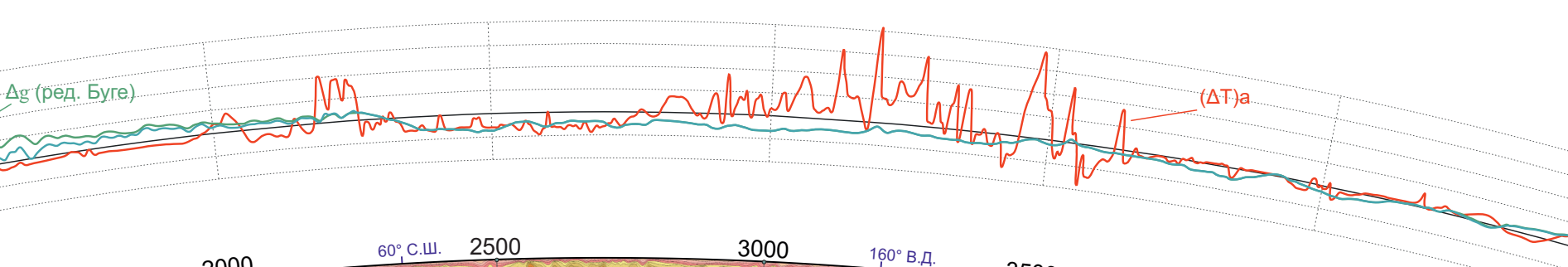

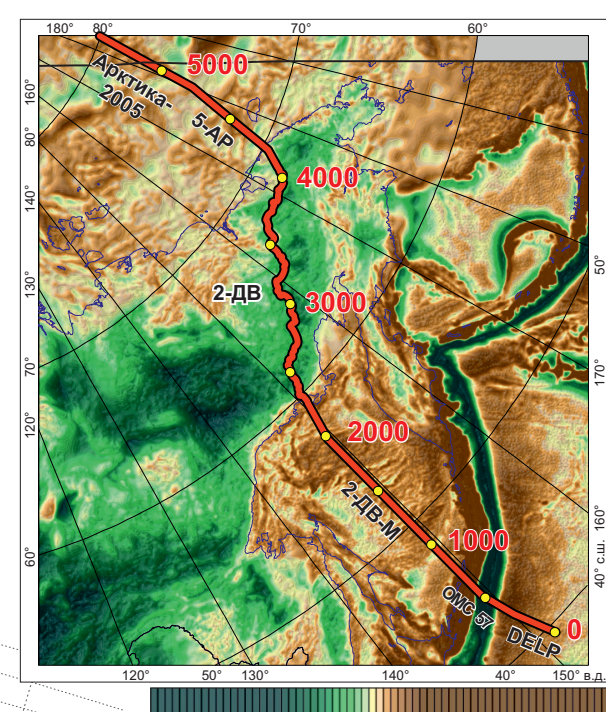

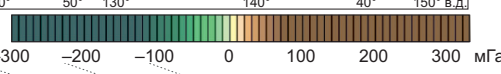

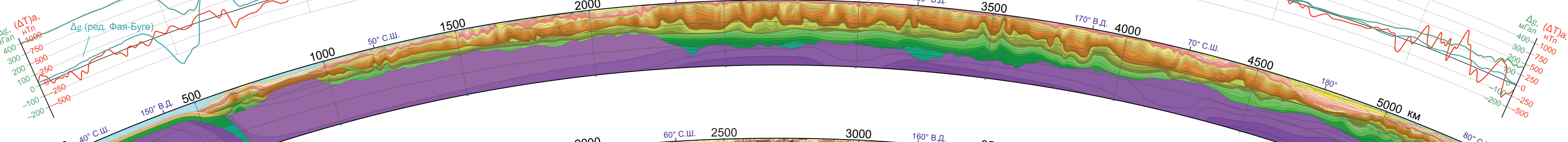

(2)

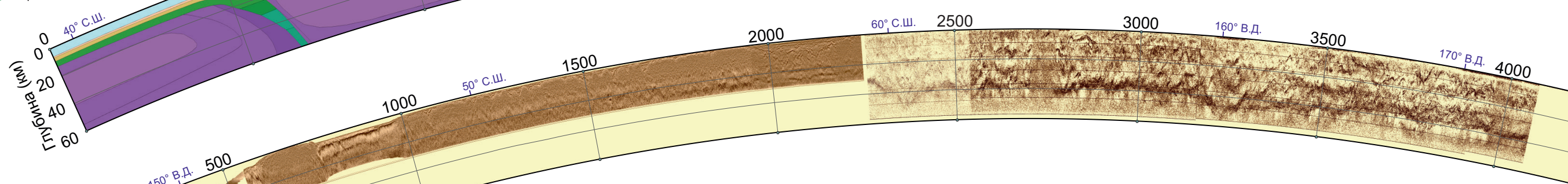

$(\partial)$

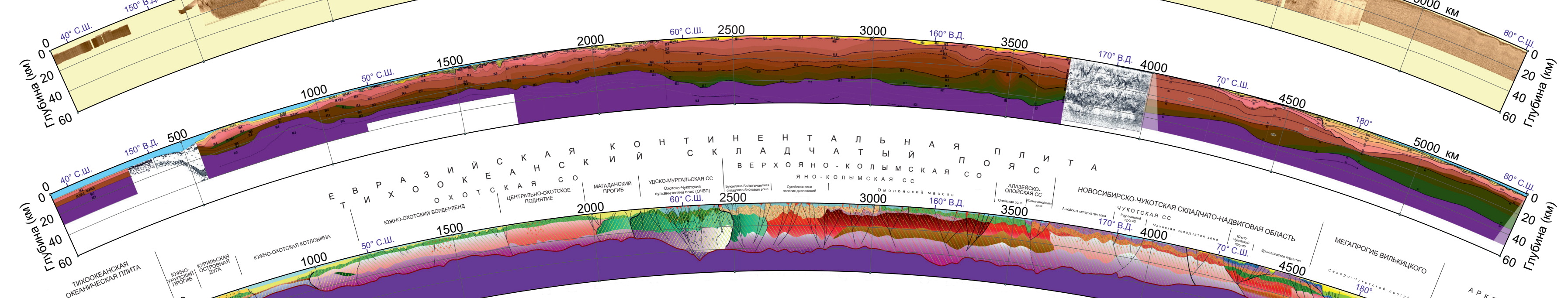

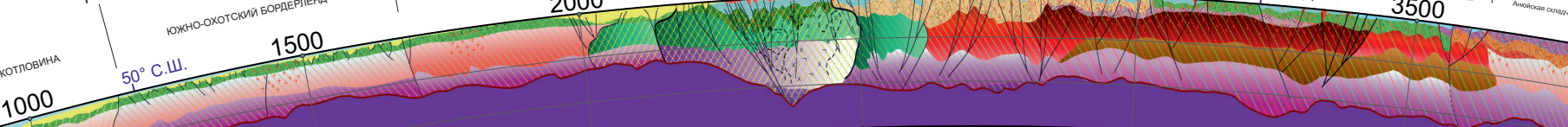

(ж)
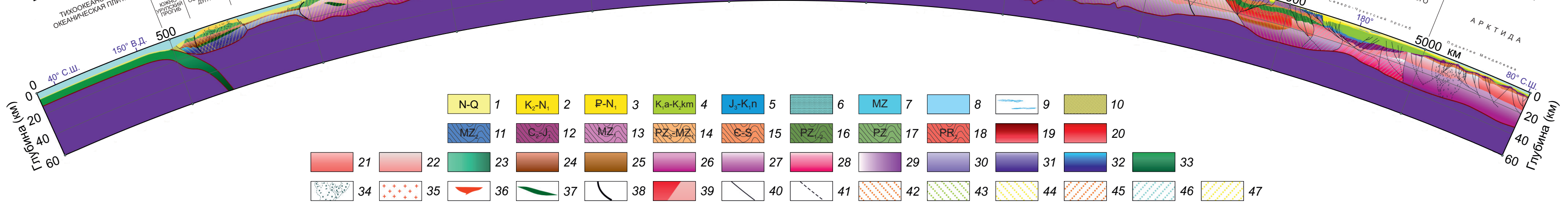
Рис. 8. Геотрансект «Тихий океан - северо-восток России - Северный Ледовитый океан».

(a) - схема расположения профиля, (б) - карта аномалий силы тяжести (комбинированная редукция Фая-Буге), (в) - графики аномалий силы тяжести в редукциях Фая-Буге и Буге $\left(2.67\right.$ г $\left./ \mathrm{cm}^{3}\right)$ и магнитных аномалий, (2) - плотностная модель, (d) - сейсмический разрез МОВ-ОГТ, (e) - скоростная модель Vp, (ж) - геолого-геофизическая модель. 1-8 - недислоцированные СВК осадочного чехла: 1 - неоген-четвертичный терригенный, 2 - верхнемеловой - нижнемиоценовый терригенный, 3 - палеоген-миоценовый вулканогенный, 4 - нижнебрукский терригенный, 5 - бофортский (синрифтовый) терригенный, 6 - осадочновулканогенный позднемезозойский, 7 - осадочно-вулканогенный мезозойский (нерасчлененный), 8 - терригенный мезозойский (нерасчлененный); 9 - клиноформные комплексы; 10 - комплексы аккреционной призмы; 11-12 - дислоцированные СВК платформенного чехла Арктиды: 11 - терригенный среднемезозойский, 12 - элсмирский карбонатно-терригенный (нерасчлененный); 13-18 - складчато-метаморфический комплекс консолидированной коры: 13 - терригенный нижнемезозойский, 14 - терригенно-карбонатный верхнепалеозойско-нижнемезозойский, 15 - франклинский терригенно-карбонатный, 16 - терригенно-карбонатный нижнесреднепалеозойский, 17 - терригенно-карбонатный палеозойский нерасчлененный, 18 - врангелевский (метавулканиты, метапесчаники, сланцы); 19-24 - верхняя кора (по времени консолидации): 19 - раннеархейская, 20 - позднеархейская, 21 - раннепротерозойская, 22 - позднепротерозойская, 23 - позднепротерозойская - раннепалеозойская, 24 - раннепалеозойская; 25 - средняя кора кратонных блоков (кристаллических массивов); 26-29 - нижняя континентальная кора: 26 - кора платформ (кристаллических массивов), 27 - кора складчатых областей, 28 - кора глубоких осадочных бассейнов, 29 - кора вулканогенно-плутонических поясов; 30-32 - нижняя переходная кора: 30 - кора задуговых бассейнов, 31 - кора островных дуг, 32 - кора зоны субдукции; 33 - нижняя океаническая кора; 34-37 - области термальной переработки коры: 34 - базификация, 35 - гранитизация, 36 - интрузивные тела кислого состава, 37 - интрузивные тела основного состава; 38-39 - границы блоков: 38 - І порядка, 39 - внутриблоковые; 40-41 - разрывные нарушения: 40 - установленные, 41 - предполагаемые; 42-44 - области проявления складчатых деформаций и метаморфизма: 42 - среднепалеозойская, 43 - позднемезозойская, 44 - кайнозойская; 45-47 - области проявления деструктивных коровых процессов: 45 среднепалеозойская, 46 - средне- и позднемезозойская, 47 - кайнозойская.

Fig. 8. Pacific Ocean - Russian Northeastern regions - Arctic Ocean geotransect.

(a) - profile location scheme, (б) - gravity anomalies map (combined Faye-Bouguer reduction), ( 8 ) - gravity anomalies in Faye-Bouguer and Bouguer reductions $\left(2.67 \mathrm{~g} / \mathrm{cm}^{3}\right)$ and magnetic anomalies, $(2)$ - density model, $(\partial)$ - CDP seismic section, $(e)-$ velocity model Vp, () - geological interpretation. 1-8 - non-deformed sedimentary cover complexes: 1 - Neogene - Quaternary, terrigenous, 2 - Upper Cretaceous - Lower Miocene, terrigenous, 3 - Paleogene - Miocene, volcanic, 4 - Lower Brookian, terrigenous, 5 - Beaufort (synrift), terrigenous, 6 - Late Mesozoic, sedimentary-volcanogenic, 7 - Mesozoic (undifferentiated), sedimentary-volcanogenic, 8 - Mesozoic (undifferentiated), terrigenous; 9 - clinoform complexes; 10 - accretionary prism complexes; 11-12 - deformed complexes of the Arctida platform cover: 11 - Middle Mesozoic, terrigenous, 12 - Ellesmerian (undifferentiated), carbonate-terrigenous; 13-18 - fold-metamorphic complex of consolidated crust: 13 - Lower Mesozoic, terrigenous, 14 - Upper Paleozoic, terrigenous-carbonate, 15 - Franklinian, terrigenous-carbonate, 16 - Lower - Middle Paleozoic, terrigenous-carbonate, 17 - Paleozoic (undifferentiated), terrigenous-carbonate, 18 - Wrangel (metavolcanic rocks, metasandstone, shale); 19-24 - upper crust (by the age of consolidation): 19 - Early Archean, 20 - Late Archean, 21 - Early Proterozoic, 22 - Late Proterozoic, 23 - Late Proterozoic - Early Paleozoic, 24 - Early Paleozoic; 25 intermediate crust of cratons (crystalline massifs); 26-29 - lower continental crust: 26 - platforms (crystalline massifs), 27 - fold areas, 28 - deep sedimentary basins, 29 - volcanic-plutonic belts; 30-32 - lower transitional crust: 30 - back-arc basins, 31 - island arcs, 32 - subduction zones; 33 - lower oceanic crust; 34-35 - crust-reworking areas: 34 - basification, 35 - granitization, 36 - felsic intrusions, 37 - mafic intrusions; 38 - boundaries of blocks, 39 - intra-block crust consolidation age transition; 40-41 - faults: 40 - proved, 41 supposed; 42-44 - areas of folding and metamorphism: 42 - Middle Paleozoic, 43 - Late Mesozoic, 44 - Cenozoic; 45-47 - areas of crustal destruction: 45 - Middle Paleozoic, 46 - Middle - Late Mesozoic, 47 - Cenozoic.

разрезы (МОВ-ОГТ, ГСЗ), плотностной разрез), дающихфактологическую базу всех дальнейших построений, которая основана на их совокупности интерпретационной геолого-геофизической моделью, что обеспечивает максимально полное и наглядное отображение исходных фактологических данных о глубинном строении, аргументирующих геолого-геофизическую интерпретацию.

На своем протяжении геотрансект пересекает ряд крупных тектонических структур (с севера на юг): поднятие Менделеева, мегапрогиб Вилькицкого (СевероЧукотский прогиб), Новосибирско-Чукотскую складчатую систему (СС) в составе Врангелевского кратонного блока (кристаллический массив) и Чукотской складчатой области, Верхояно-Колымскую складчато-надвиговую систему в составе Омолонского кратонного (кристаллического) массива, Алазейско-Олойской и Яно-Колымской СС, Удско-Мургальскую СС, Охотскую складчатую область, Южно-Охотскую котловину и Курильскую островную дугу.

Легендой к геотрансекту предусмотрены условные знаки для обозначения структурно-вещественных комплексов складчато-метаморфического и кристаллического фундамента структур консолидированной коры. Последние несогласно перекрываются меловыми вулканическими образованиями Охотско-Чукотского и Удско-Мургальского поясов (преимущественно основного или кислого состава), терригенными угленосными комплексами рифтогенных мезозойских и кайнозойских впадин и формирующимся осадочным чехлом охотоморского шельфового бассейна. Глубинные комплексы кристаллического фундамента разделены на верхне-, средне- и нижнекоровые, показанные градиентной вертикальной заливкой. Внутри крупных тектонических единиц выделены так называемые «ядра консолидации», представляющие наиболее древние 
фрагменты коры, которые облекаются более молодыми блоками. Латеральное деление коры соответствует ее генетическому типу согласно работе [Kashubin et al., 2018b]. В пределах профиля выделены континентальная, переходная и океаническая кора. Континентальная кора, в свою очередь, подразделяется на кору платформ (кратонных массивов), складчатых областей, глубоких осадочных бассейнов и вулканогенно-плутонических поясов. В пределах переходной коры выделяются задуговые бассейны, островные дуги и зоны субдукции. Эти характеристики в большей степени отвечают нижней коре, как несущей, по нашему мнению, основную генетическую информацию о строении крупных тектонических единиц.

Верхняя кора в пределах выделенных блоков дифференцирована по возрасту консолидации земной коры в соответствии с геологическими данными по крупным тектоническим элементам и их окружению. Особыми знаками показаны на разрезе такие геолого-геофизические границы, как подошва осадочного чехла, подошва складчатого фундамента, кровля нижней коры и граница Мохо. Дополнительными знаками на разрезе отмечены значения скоростных и плотностных параметров для различных уровней земной коры. В процессе интерпретации выполнен анализ тектонической обстановки с целью выявления магматических образований; выделены зоны повышенной тектономагматической активности в верхней части разреза, разделенные по их специализации: гранитизации и базификации.

По строению консолидированной коры в полосе геотрансекта четко обособляются несколько крупных блоков (с севера на юг): отличающаяся повышенной мощностью нижнего слоя кора поднятия Менделеева; подвергнутая деструкции с мощным осадочным чехлом кора Северо-Чукотского прогиба; мощная, предположительно, древняя кора поднятия Врангеля-Геральда (Врангелевского кратонного блока или кристаллического массива); практически лишенная осадочного чехла низкоскоростная кора Чукотской складчатой области; мощная древняя трехслойная континентальная кора Омолонского кратонного блока (кристаллического массива) и его северной окраины; подвергнутая деструкции двухслойная кора его южной окраины; характеризующаяся повышенной мощностью нижнего слоя кора Удско-Мургальского блока; подвергнутая позднекайнозойскому растяжению маломощная континентальная кора Охотоморского бассейна; сильно изменчивая по своим характеристикам переходная кора зоны «задуговый бассейн - вулканическая дуга - зона субдукции» и океаническая кора Тихоокеанской плиты.

Разрез земной коры в пределах геолого-геофизической модели по геотрансекту изучен на всю ее мощность. Поверхность Мохо прослежена на глубинах от 10 до 52 км. Наиболее простое строение верхней мантии отмечено под структурами Верхояно-Колымской и Охотской складчатых областей, наиболее сложное - под
Врангелевским кратонным массивом, Северо-Чукотским прогибом и Удско-Мургальским блоком, где выделяется одновременно подъем относительно высокоскоростной и высокоплотностной мантии, а также на северной оконечности Омолонского массива и в пределах Южно-Анюйской зоны, где обособляется фрагмент мантии с аномально низкой плотностью и скоростью (до 7.8 км/с), непосредственно ниже границы М. Под Южно-Охотской котловиной фиксируются признаки расслоения верхней мантии. На южной оконечности профиля в мантию уходит слэб океанической коры, погружающейся под континентальную кору.

Мощность земной коры варьируется в широких пределах - от 10-12 км в пределах Южно-Охотской котловины и 28-30 км в пределах рифтогенных прогибов Северо- и Южно-Чукотского и Магаданского до 40-42 км во Врангелевском кратонном блоке и 50-52 км в УдскоМургальской СС и на севере Омолонского массива, испытывая общую тенденцию к уменьшению в южном направлении в сторону океана.

Структурный образ коры и полученные скорости ГСЗ с определенной условностью позволяют в пределах древних Врангелевского и Омолонского кратонных массивов и их окраин разделить ее на три части - нижнюю, среднюю и верхнюю. В остальных блоках кора двуслойная.

В рамках арктической пассивной окраины в пределах геотрансекта обособляются два древних кратонных блока: Врангелевский и Менделеева, разделенных Северо-Чукотским прогибом. Они различаются глубинным строением, возрастом кратонизации и историей геологического развития [Kashubin et al., 2018d].

Врангелевский кратонный блок (поднятие Врангеля-Геральда) является наиболее древним по возрасту коры и может рассматриваться как достаточно крупный осколок Сибирского кратона, отторгнутый от последнего в ходе раннекаледонских событий в район будущей аккреционно-коллизионной системы ранних мезозоид. Он обладает корой мощностью от 30 до 35 км, уменьшающейся на север в сторону Северо-Чукотского прогиба. При этом мощность ее кристаллической части изменяется от 18 до 25 км с той же тенденцией уменьшения в северном направлении. Если на юге блока нижний и верхний слои имеют примерно равные мощности по 15 км, то на севере нижний слой составляет 10 км, тогда как верхний слой уменьшается до 8 км. На наш взгляд, это свидетельство рифтогенных процессов, наложенных на северный борт Врангелевского поднятия в конце девона - начале карбона, а затем и в середине юры. Плотностная модель демонстрирует ярко выраженную вертикальную и латеральную неоднородность консолидированной коры в пределах массива. Можно предположить, что латеральная неоднородность обусловлена как дизъюнктивной тектоникой, так и формационными изменениями. Южная граница массива может быть проведена по резким изменениям глубины залегания кровли верхней коры и увеличению мощности коры за счет ее кристаллической части. Северная 
граница массива проходит под западным бортом Северо-Чукотского прогиба. Вероятнее всего, границы массива имеют тектоническую природу.

Еще одной установленной особенностью является увеличение скоростей Vр в нижней коре в северном направлении от 6.7 до 7.0 км/с. Это можно объяснить как рифтогенными процессами и поднятием мантии, так и достаточно древним возрастом коры не только центральной части Врангелевского поднятия (архейский - нижнепротерозойский), но и его периферийных частей (неопротерозойский).

Кратонный блок Менделеева имеет, по-видимому, фундамент неопротерозойского возраста и может рассматриваться как фрагмент древнего материка Арктида. Скоростные и плотностные параметры коры позволили представить на разрезе поднятие Менделеева как блок двухслойной позднедокембрийской континентальной кристаллической коры мощностью до 30 км и предположить наличие в составе его акустического фундамента позднепротерозойских(?), палеозойских и раннемезозойских отложений чехла кратона Арктида. Нижняя кора здесь характеризуется повышенными, по сравнению с южными блоками, скоростями распространения продольных волн от 6.8 до 7.2 км/с и достаточно большой и хорошо выдержанной по простиранию мощностью до 20 км при общей мощности коры в 32-34 км.

Северо-Чукотский прогиб, входящий в систему мегапрогиба Вилькицкого, рассматривается как рифтогенный с двумя циклами рифтогенных процессов: постэлсмирским и мезозойским. Под ним фиксируется растянутая кора общей мощностью 28-30 км. Из них до 14-16 км занимает осадочный чехол, 2-4 км - супракрустальный (переходный) комплекс и менее 10-12 км кристаллическая кора. Мощность переработанной верхней коры в центральной части данного блока, четко фиксируемой по скорости распространения продольных волн 6.2 км/с и отношению Vp/Vs 1.71-1.73, сокращается до 3-5 км. Скорости распространения продольных волн в нижней коре увеличиваются в северном направлении до 6.9-7.0 км/с.

К югу от Врангелевского кратонного блока развиты мезозоиды Чукотской складчатой области, являющейся южным окончанием Новосибирско-Чукотской складчатой системы мезозоид. В ее составе по особенностям геологического строения выделяются (с севера на юг) две протяженные субширотные складчатые зоны мезозоид: Чаунская и Анюйская и разделяющий их наложенный Раучуанский прогиб. На юге ее граница перекрыта вулканитами Охотско-Чукотского пояса.

Геотрансектом изучено строение зоны сочленения Верхояно-Колымской и Новосибирско-Чукотской складчато-надвиговых систем. Переход от первой ко второй сопровождается быстрым снижением общей мощности коры от 48 до 40 км (на 40-километровом расстоянии от восточной границы Южно-Анюйской зоны по профилю) и далее до 35 и даже 30 км в Чаунской зоне. При этом утоняется, в первую очередь, относительно плотная нижняя кора (доходя до 7-8 км мощности под Южно-Чукотским прогибом) при сохранении в большинстве случаев средней толщины верхнего складчато-метаморфического «слоя» и гранитно-метаморфической кристаллической коры, которые испытывают резкие согласованные колебания толщины, из-за чего утолщенная кристаллическая кора в местах утонения складчатого слоя может близко подходить к земной поверхности и даже давать коренные выходы и разрушаться. Южно-Анюйская зона - важнейший элемент современных палеотектонических реконструкций, принимаемая многими исследователями за коллизионную (сутурную) зону - след закрывшегося позднепалеозойско-раннемезозойского Протоарктического океана. Приходится констатировать, что, несмотря на ее явный шовный пограничный характер (резкое изменение мощности и состава коры), в пределах геотрансекта на разрезе МОВ-ОГТ не зафиксировано площадок и высокоэнергетических отражений, уходящих в мантию.

Расположенная южнее Алазейско-Олойская СС представляет собой северное преобразованное окончание Омолонского массива. Структурный образ коры, полученные скорости ГСЗ и плотностная модель с определенной условностью в его пределах и в пределах его континентальных окраин позволяют разделить кору на три части - нижнюю, среднюю и верхнюю. Это еще раз подчеркивает древний кратонный характер как данной структуры, так и его переработанных окраин (Алазейско-Олойской СС и Сугойской зоны пологих дислокаций), делая массив одним из центров кратонизации и аккреционной деятельности в регионе. Он обладает трехслойной корой мощностью до 48-52 км, уменьшающейся на юг в сторону его южной окраины до 36-40 км. При этом мощность ее кристаллической части в пределах массива изменяется от 35-40 км в северной части до 18-20 км на его южной окраине с четкой тенденцией уменьшения в южном направлении. Строение коры массива четко свидетельствует о явно выраженной вертикальной и латеральной неоднородности. Под его северной частью по данным ГСЗ и плотностного моделирования выделена низкоскоростная мантия со скоростью 7.8 км/с и плотностью 3.2 г/ $\mathrm{cm}^{3}$.

Юго-западная граница массива по верхним горизонтам проводится в зоне погружения палеозойских образований, выходящих к поверхности на Южно-Омолонском поднятии, по глубоким комплексам коры - в зоне резкого взброса нижнекоровых пакетов отражений, с увеличением мощности нижней коры в Сугойской зоне пологих дислокаций, заложенной на окраине Омолона, до 14-16 км при общей мощности коры 40-44 км. К этой границе в низах коры приурочена локально развитая линза коромантийной смеси с плотностями вмещающего вещества 3.15 г/ $\mathrm{cm}^{3}$.

К Сугойской зоне пологих дислокаций, разделенных зоной Омсукчанского глубинного разлома, с юга непосредственно примыкает узкая по линии профиля Буюндино-Балыгычанская складчато-блоковая зона собственно Яно-Колымской СС. Именно он, как нам 
представляется, разделяет два крупных блока земной коры: Яно-Колымский (на юге) и Омолонский (на севере).

Очевидно, что Буюндино-Балыгычанская складчато-блоковая зона является пограничной структурой с расположенной с юга Удско-Мургальской СС, представляя собой юго-восточный узкий фрагмент складчатых зон мезозоид Яно-Колымской СС, что достаточно рельефно выражено на профиле. Вероятно, этот блок сформировался в результате неоднократных сложных сдвигово-надвигово-взбросовых процессов, следствием которых является локальное сжатие земной коры под действием сближения крупных разнонаправленных мегаструктур. Этим может быть объяснено увеличение мощности верхней коры до 24 км при общей мощности кристаллической коры в пределах данной структуры Яно-Колымской и Удско-Мургальской СС, приходящейся как раз на южную окраину этого блока.

Таким образом, Буюндино-Балыгычанская складчато-блоковая зона Яно-Колымской СС и Удско-Мургальская СС оказались зажатыми между Омолонским древним массивом и структурами Охотского блока, по нашему мнению, проработанной акваториальной окраины Охотского массива. Сложная внутренняя структура этой зоны, отраженная на разрезе по геотраверсу, обусловлена многократной проработкой коры как в условиях сжатия, так и в условиях растяжения с неоднократным проявлением мощных процессов флюидо-магматической ее проработки.

Удско-Мургальский блок рассматривается нами как зона сочленения принципиально разных по своему глубинному геологическому строению блоков земной коры. Начинается разрез коры с линзы коромантийной

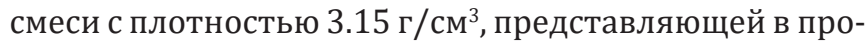
екции на вертикальную плоскость разреза почти равнобедренный треугольник. Строение блока асимметрично; общая мощность коры в его северной (континентальной) части доходит до 50 км, тогда как у южной границы под Магаданским прогибом уменьшается до 25-27 км. При этом мощность ее кристаллической части составляет 36-38 км на севере, уменьшаясь до 2224 км к югу. Из них на севере существенно более половины (до 22 км) составляет нижняя кора со скоростями 6.6-6.8 км/с, сокращаясь на юге до 7-8 км; верхняя кора со скоростями 6.2-6.4 км/с распределена более равномерно, достигая значений мощности в 16-18 км. Такая кора выделена нами в отдельный тип континентальной коры вулканогенно-плутонических поясов.

При переходе от континента к акватории Охотского моря отмечено уменьшение мощности коры. Приведшие к этому деструктивные преобразования, скорее всего, были вызваны подъемом мантийного диапира и обусловили растяжение континентальной коры, уменьшение ее мощности (до 20-22 км и менее в южных частях акватории в районе Южно-Охотского бордерленда), формирование сводового поднятия (Центрально-Охотский) и обрамляющего его пояса кайнозойских прогибов (Магаданского, например, наложенного в кайнозое на глубинный шов между Удско-Мургальской и Охотской СС).

Центрально-Охотское поднятие вместе со структурами Южно-Охотского бордерленда (ПК 3720-4250) обладает древней континентальной корой, подвергшейся различным деструктивным преобразованиям, которые привели к ее утонению до 25 км - в пределах поднятия и 20 км - в районе бордерленда. Трактовка Охотоморской плиты некоторыми представителями геологического сообщества как части верхнемеловой океанической плиты Кула не соответствует современной геолого-геофизической информации и противоречит материалам по данному сводному геотрансекту.

Тренд последовательного сокращения мощности коры, и особенно консолидированной ее части, еще больше усиливается при приближении к Курильским островам. Основные изменения в геологическом строении акватории Охотского моря происходят на северном склоне Южно-Охотской котловины, который является своеобразным морфологическим репером, отделяющим эту глубоководную впадину от Центрально-Охотского свода. Общая мощность коры южнее этого репера сокращается до 10 км, причем изменения касаются как осадочной, так и консолидированной части коры. В качестве главного фактора, определившего геодинамику развития этого региона начиная с миоцена, может рассматриваться процесс деламинации, связанный с внедрением мантийного диапира и вызвавший растяжение континентальной земной коры в области современной котловины, вертикальную аккрецию консолидированной коры сопредельных структур и активную магматическую деятельность. Несмотря на уменьшенную мощность консолидированной части, земная кора этой структуры сохраняет тонкую верхнюю кору [Pavlenkova et al., 2018; Kashubin, Petrov, 2019].

Южный борт Южно-Охотской котловины системой сложных сбросов с явно сдвиговой компонентой отделен от Курильской островной дуги. Особенности ее современного глубинного строения в значительной степени определяются вулканическими процессами. Мощность коры в ее пределах 20-22 км, существенно преобладает нижнекоровый слой (до 13-15 км). Установлено весьма примечательное поведение верхнекорового слоя: он развит неравномерно, его мощность резко увеличивается в южном направлении в три раза - от 2 до 6 км вместе с увеличением плотности от 2.78 до 2.88 г/ $\mathrm{cm}^{3}$ при скорости 6.0-6.2 км/с. Это может говорить о продолжающихся процессах растяжения коры и ее преобразовании за счет современного основного вулканизма.

Геотрансект наглядно характеризует строение зоны субдукции Тихоокеанской плиты под Евразийскую. Сама зона субдукции выделяется нами по данным сейсмологии как сейсмофокальная зона с падением порядка $35-45^{\circ}$ в направлении континента. Проекции на линию разреза очагов землетрясений в этой зоне, представляющей переход от Тихоокеанской плиты к Евразийскому континенту, образуют достаточно широкую 
полосу. Ее ширина примерно коррелируется с мощностью совмещенных по этой зоне разрезов континентальной и пододвигаемой под нее океанической коры. Раздув мощности слэба до 15 км как раз и объясняется желанием авторов учесть данные по очагам землетрясений. Выделены элементы аккреционной призмы геологического тела, формирующегося в ходе погружения океанической коры Тихоокеанской плиты в мантию во фронтальной части вышележащей Евразийской плиты. Достаточно высокие скорости (около 5.0 км/с) в ее пределах объясняются многочисленным наслоением осадочных пород обеих плит и сильной деформацией нагромождаемого материала, разрушаемого бесконечными надвигами. Аккреционная призма на линии геотраверса располагается между глубоководным желобом и преддуговым Южно-Урупским прогибом (бассейном).

Таким образом, сводный геотрансект демонстрирует, что все основные структурно-вещественные комплексы земной коры (несмотря на их различный генетический тип) непрерывно прослеживаются от арктической континентальной окраины через мезозоиды северо-востока России в акваторию Охотского моря и фиксируются, постепенно уменьшаясь в мощности, на всем протяжении профиля, вплоть до Курильской (Южно-Охотской) котловины.

\section{5. ЗАКЛЮЧЕНИЕ}

Обобщение и интерпретация комплекса региональных геофизических данных, выполненные в рамках международного проекта «Глубинные процессы и металлогения Северной, Центральной и Восточной Азии», позволили охарактеризовать глубинное строение земной коры северо-восточного сегмента Евразии и на этой основе создать предпосылки для решения ряда важных с практической и научной точки зрения задач. Основные результаты обобщения сводятся к следующему:

1. Впервые в мировой практике созданы карты глубинного строения столь высокой детальности на весьма обширный и значимый в тектоническом отношении регион мира общей площадью свыше 50 млн км². Карты свидетельствуют о существенной неоднородности глубинного строения как для региона в целом, так и в пределах отдельных региональных структур. Высокая детальность карт демонстрирует не только общий тренд закономерного уменьшения мощности земной коры от центральной части Евразии к ее арктической и тихоокеанской окраинам, но и локальные особенности рельефа подошвы земной коры, в частности в узких областях внутриконтинентальных шовных зон.

2. Установленные закономерности распределения генетических типов и подтипов земной коры в пределах Евразийского континента и его пассивной (арктической) и активной (тихоокеанской) окраин показывают, что уменьшение мощности консолидированной коры от центральной части континента к его окраинам связано с переходом от преимущественно трехслойной кристаллической коры в центре континента к двухслойной консолидированной коре на окраинах континента и в пределах шельфовых морей. В регионе преобладает континентальный тип земной коры. При этом континентальный тип сохраняется не только в пределах области Центрально-Арктических поднятий - одного из наиболее удаленных элементов пассивной окраины континента, но и в пределах Курильской (Южно-Охотской) котловины, находящейся в непосредственной близости от зоны субдукции, разделяющей активную тихоокеанскую континентальную окраину и Тихоокеанскую океаническую плиту.

3. Опорная геолого-геофизическая модель по геотрансекту протяженностью 5400 км, дополняющему комплект карт глубинного строения информацией о вертикальном сечении глубинных геологических структур, позволяет понять их морфологию и взаимоотношение с картируемыми геологическими образованиями. Это дает возможность анализировать представленные в рамках модели разрезы со структурно-геологических позиций, выявляя характерные для определенных тектонических режимов структурные ансамбли.

4. Рассматриваемая совокупность карт и разрезов позволяет выявить особенности строения сложных многоярусных районов, где наблюдается несоответствие структурного плана верхнего складчатого этажа и кристаллического основания. Эти данные могут явиться основой для принципиально нового структурно-тектонического районирования Северо-Восточной Евразии с учетом особенностей строения земной коры и верхней мантии как самих региональных структур, так и зон их сочленения. Последнее может представлять особый интерес для прогнозно-минерагенических построений.

\section{6. БЛАГОДАРНОСТИ}

Авторы выражают признательность зарубежным коллегам по проекту «Глубинные процессы и металлогения Северной, Центральной и Восточной Азии», предоставившим геофизические данные по своим территориям. Особенно существенный вклад внесли китайские исследователи D. Shuwen и L. Qiusheng. Авторы также благодарят своих российских коллег, принимавших участие в обработке геофизических материалов и предварительных обсуждениях результатов исслеований, - Ю.М. Эринчека, Т.П. Литвинову, Т.С. Сакулину, Д.В. Вяткину, Ю.С. Голышеву, Т.В. Кашубину, Н.А. Крупнову, В.Н. Мухина, А.В. Рыбалку, С.В. Суслову, Т.М. Яварову.

\section{7. ЛИТЕРАТУРA/REFERENCES}

Aleinikov A.L., Nemzorov N.I., Kashubin S.N., 1991. Method for Determining Rock Types from Seismic Data. Author Certificate N 1642416 A1 cl. G 01 V1/30 (in Russian) [Алейников А.Л., Немзоров Н.И., Кашубин С.Н. Способ определения типа горных пород по сейсмическим данным: Авторское свидетельство N 1642416 А1 кл. G 01 V1/30. 1991].

Belousov V.V., Pavlenkova N.I., 1989. Types of Crust in Europe and North Atlantic. Geotectonics 3, 3-14 (in Russian) 
[Белоусов В.В., Павленкова Н.И. Типы земной коры Европы и Северной Атлантики // Геотектоника. 1989. № 3. C. 3-14].

Belousov V.V., Pavlenkova N.I., Kvyatkovskaya G.I. (Eds), 1991. Deep Structure of the USSR Territory. Nauka, Moscow, 224 p. (in Russian) [Глубинное строение территории СССР / Ред. В.В. Белоусов, Н.И. Павленкова, Г.И. Квятковская. М.: Наука, 1991. 224 с.].

Breivik A.J., Mjelde R., Grogan P., Shimamura H., Murai Y., Nishimura Y., 2005. Caledonide Development OffshoreOnshore Svalbard Based on Ocean Bottom Seismometer, Conventional Seismic, and Potential Field Data. Tectonophysics 401 (1-2), 79-117. https://doi.org/10.1016/j.tecto. 2005.03.009.

Buchan K.L., Ernst R.E., 2006. The High Arctic Large Igneous Province (HALIP): Evidence for an Associated Giant Radiating Dyke Swarm. LIP of the Month. Available from: http://www.largeigneousprovinces.org/06apr (Last Accessed 24.05. 2020).

Demenitskaya R.M., 1975. The Earth's Crust and Mantle. Nedra, Moscow, 256 p. (in Russian) [Деменицкая Р.М. Кора и мантия Земли. М.: Недра, 1975. 256 с.].

Druzhinin V.S., Egorkin A.V., Kashubin S.N., 1990. New DSS Data on the Deep Structure of the Urals and Neighbouring Regions. Doklady of the USSR Academy of Sciences 315 (5), 1086-1090 (in Russian) [Дружинин В.С., Егоркин А.В., Кашубин С.Н. Новые данные о глубинной структуре Урала и прилегающих к нему областей по данным ГСЗ // Доклады АН СССР. 1990. Т. 315. № 5. С. 1086-1090].

Druzhinin V.S., Karetin Yu.S., Kashubin S.N., 2000. Deep Geo-Mapping of the Urals Region Based on DSS Data. Regional Geology and Metallogeny 10, 152-161 (in Russian) [Дружинин В.С., Каретин Ю.С., Кашубин С.Н. Глубинное геокартирование Уральского региона по данным ГСЗ // Региональная геология и металлогения. 2000. № 10. C. 152-161].

Druzhinin V.S., Kashubin S.N., Kashubina T.V., Kolmogorova V.V., Parygin G.V., Rybalka A.V., Tiunova A.M., 1997. The Main Features of the Interface between the Crust and the Upper Mantle in the Middle Urals (in Vicinity of the Deep Drillhole SG-4). Tectonophysics 269 (3-4), 259-267. https://doi.org/10.1016/S0040-1951(96)00163-1.

Egorkin A.V., Akinshina L.V., Artemenko L.S., Danilova T.I., 2002. Structure of the Crystalline Crust of Siberia along the Khanty-Mansiysk - Lena line. Prospect and Protection of Mineral Resources 2, 32-33 (in Russian) [Егоркин А.В., Акиншина Л.В., Артеменко Л.С., Данилова Т.И. Строение кристаллической коры Сибири по линии Ханты-Мансийск Лена // Разведка и охрана недр. 2002. № 2. С. 32-33].

Embry A.F., 1991. Mesozoic History of the Arctic Islands. In: H.P. Trettin (Ed.), Geology of the Innuitian Orogen and Arctic Platform of Canada and Greenland. Geological Society of America 3, 371-433. https://doi.org/10.1130/DNAGGNA-E.369.

Erinchek Yu.M. (Ed.), 2007. Models of the Earth's Crust and Upper Mantle by Deep Seismic Profiling. Proceedings of the International Symposium (September 18-20, 2007). VSEGEI Publishing House, Saint Petersburg, 245 p. (in Russian)
[Модели земной коры и верхней мантии по результатам глубинного сейсмопрофилирования: Материалы Международного научно-практического семинара (1820 сентября 2007 г.) / Ред. Ю.М. Эринчек. СПб.: Изд-во ВСЕГЕИ, 2007. 245 с.].

Estrada S., Henjes-Kunst F., Höhndorf A., 1999. Cretaceous Volcanites from the Canadian Arctic Islands: Magmatism Related to the Opening of the Arctic Ocean. European Journal of Mineralogy 11 (1), 66.

Funck T., Jackson H.R., Shimeld J., 2011. The Crustal Structure of the Alpha Ridge at the Transition to the Canadian Polar Margin: Results from a Seismic Refraction Experiment. Journal of Geophysical Research: Solid Earth 116 (B12). https://doi.org/10.1029/2011JB008411.

Gaina C., Werner S.C., Saltus R., Maus S. and the CAMP-GM Group, 2011. Circum-Arctic Mapping Project: New Magnetic and Gravity Anomaly Maps of the Arctic. In: A.M. Spencer, A. Embry, D.L. Gautier, A.V. Stoupakova, K. Sørensen (Eds), Arctic Petroleum Geology. Geological Society London Memoirs 35(1), 39-48. https://doi.org/10.1144/M35.3.

Grad M., Tiira T., ESC Working Group, 2009. The Moho Depth Map of the European Plate. Geophysical Journal International 176 (1), 279-292. https://doi.org/10.1111/ j.1365-246X.2008.03919.x.

Iwasaki T., Levin V., Nikulin A., Iidaka T., 2013. Constraints on the Moho in Japan and Kamchatka. Tectonophysics 609, 184-201. https://doi.org/10.1016/j.tecto.2012.11.023.

Jackson H.R., Dahl-Jensen T., the LORITA Working Group, 2010. Sedimentary and Crustal Structure from the Ellesmere Island and Greenland Continental Shelves onto the Lomonosov Ridge, Arctic Ocean. Geophysical Journal International 182 (1), 11-35. https://doi.org/10.1111/j.1365246X.2010.04604.x.

Jokat W., Schmidt-Aursch M.C., 2007. Geophysical Characteristics of the Ultraslow Spreading Gakkel Ridge, Arctic Ocean. Geophysical Journal International 168 (3), 983-998. https://doi.org/10.1111/j.1365-246X.2006.03278.x.

Kanao M., Suvorov V.D., Toda S., Tsuboi S., 2015. Seismicity, Structure and Tectonics in the Arctic Region. Geoscience Frontiers 6 (5), 665-677. https://doi.org/10.1016/j. gsf.2014.11.002.

Kashubin S.N. (Ed.), 2002. Geotraverse GRANITE. East European Platform - Ural - West Siberia (Crustal Structure Based on Results of Complex Geological and Geophysical Studies). Ekaterinburg, 312 p. (in Russian) [Геотраверс «ГРАНИТ»: Восточно-Европейская платформа - Урал Западная Сибирь (строение земной коры по результатам комплексных геолого-геофизических исследований) / Ред. С.Н. Кашубин. Екатеринбург, 2002. 312 с.].

Kashubin S.N., Milshtein E.D., Vinokurov I.Yu., Erinchek Yu.M., Serzhantov R.B., Tatarinov V.Yu., 2016a. State Network of Geotransects and Superdeep Wells - the Basis for 3D Deep Mapping of the Russian Federation and Its Continental Shelf. Regional Geology and Metallogeny 67, 43-48 (in Russian) [Кашубин С.Н., Мильштейн Е.Д., Винокуров И.Ю., Эринчек Ю.М., Сержантов Р.Б., Татаринов В.Ю. Государственная сеть опорных геолого-геофизических профилей, параметрических и сверхглубоких 
скважин - основа глубинного 3D картографирования территории Российской Федерации и ее континентального шельфа // Региональная геология и металлогения. 2016. № 67. С. 43-48].

Kashubin S.N., Pavlenkova N.I., Petrov O.V., Milshtein E.D., Shokalsky S.P., Erinchek Yu.M., 2013. Types of Crust in the Circumpolar Arctic. Regional Geology and Metallogeny 55, 5-20 (in Russian) [Кашубин С.Н., Павленкова Н.И., Петров О.В., Мильштейн Е.Д., Шокальский С.П., Эринчек Ю.М. Типы земной коры Циркумполярной Арктики // Региональная геология и металлогения. 2013. № 55. C. 5-20].

Kashubin S.N., Petrov O.V. (Eds), 2019. Shear and Converted Waves in Marine Deep Seismic Studies. Proceedings of VSEGEI. New Series. Vol. 360. VSEGEI, Saint Petersburg, 155 p. (in Russian) [Поперечные и обменные волны при глубинных сейсмических исследованиях на акваториях // Труды ВСЕГЕИ. Новая серия / Ред. С.Н. Кашубин, О.В. Петров. СПб.: ВСЕГЕИ, 2019. Т. 360.155 с.].

Kashubin S.N., Petrov O.V., Androsov E.A., Morozov A.F., Kaminsky V.D., Poselov V.A., 2011a. Crustal Thickness Map of Circumpolar Arctic. Regional Geology and Metallogeny 46, 5-13 (in Russian) [Кашубин С.Н., Петров О.В., Андросов Е.А., Морозов А.Ф., Каминский В.Д., Поселов В.А. Карта мощности земной коры Циркумполярной Арктики // Региональная геология и металлогения. 2011. № 46. С. 5-13].

Kashubin S.N., Petrov O.V., Androsov E.A., Morozov A.F., Kaminsky V.D., Poselov V.A., 2014. Crustal Thickness in the Circum Arctic. In: D.B. Stone, G.E. Grikurov, J.G. Clough, G.N. Oakey, D.K. Thurston (Eds), ICAM VI: Proceedings of the International Conference on Arctic Margins VI (Fairbanks, Alaska, May 2011). VSEGEI Publishing House, Saint Petersburg, p. 1-17.

Kashubin S.N., Petrov O.V., Artemieva I.M., Morozov A.F., Vyatkina D.V., Golysheva Yu.S., Kashubina T.V., Milshtein E.D., Rybalka A.V., Erinchek Yu.M. et al., 2016b. Deep Structure of Crust and the Upper Mantle of the Mendeleev Rise on the Arctic-2012 DSS Profile. Regional Geology and Metallogeny 65, 16-35 (in Russian) [Кашубин С.Н., Петров О.В., Аpтемьева И.М., Морозов А.Ф., Вяткина Д.В., Голышева Ю.С., Кашубина Т.В., Мильштейн Е.Д., Рыбалка А.В., Эринчек Ю.М. и др. Глубинное строение земной коры и верхней мантии поднятия Менделеева по профилю ГСЗ Арктика-2012 // Региональная геология и металлогения. 2016. № 65. C. 16-35].

Kashubin S.N., Petrov O.V., Artemieva I.M., Morozov A.F., Vyatkina D.V., Golysheva Yu.S., Kashubina T.V., Milshtein E.D., Rybalka A.V., Erinchek Yu.M. et al., 2018a. Crustal Structure of the Mendeleev Rise and the Chukchi Plateau (Arctic Ocean) along the Russian Wide-Angle and Multichannel Seismic Reflection Experiment «Arctic-2012». Journal of Geodynamics 119, 107-122. https://doi.org/10.1016/j.jog. 2018.03.006.

Kashubin S.N., Petrov O.V., Milshtein E.D., Androsov E.A., Vinokurov I.Yu., Shokalsky S.P., 2018b. Crustal Types of Central and Northeast Asia, Far Eastern and Arctic Continent Ocean Transition Ares. Regional Geology and Metallogeny
73, 6-18 (in Russian) [Кашубин С.Н., Петров О.В., Мильштейн Е.Д., Андросов Е.А., Винокуров И.Ю., Шокальский С.П. Типы земной коры Центральной и СевероВосточной Азии, дальневосточной и арктической областей перехода континент - океан // Региональная геология и металлогения. 2018. № 73. С. 6-18].

Kashubin S.N., Petrov O.V., Milshtein E.D., Kudryavtsev I.V., Androsov E.A., Vinokurov I.Yu., Tarasova O.A., Erinchek Yu.M., 2018c. Deep Structure of the Earth's Crust and Upper Mantle in Northeastern Eurasia. Regional Geology and Metallogeny 76, 9-21(in Russian) [Кашубин С.Н., Петров О.В., Мильштейн Е.Д., Кудрявцев И.В., Андросов Е.А., Винокуров И.Ю., Тарасова О.А., Эринчек Ю.М. Глубинное строение земной коры и верхней мантии Северо-Восточной Евразии // Региональная геология и металлогения. 2018. № 76. C. 9-21].

Kashubin S.N., Petrov O.V., Milshtein E.D., Vinokurov I.Yu., Androsov E.A., Golysheva Yu.S., Efimova N.N., Yavarova T.M., Morozov A.F., 2018d. Earth's Crust Structure of the Mendeleev Rise and Its Connection with Eurasian Continent (by Geophysical Data). Regional Geology and Metallogeny 74, 5-18 (in Russian) [Кашубин С.Н., Петров О.В., Мильштейн Е.Д., Винокуров И.Ю., Андросов Е.А., Голышева Ю.С., Ефимова Н.Н., Яварова Т.М., Морозов А.Ф. Структура земной коры зоны сочленения поднятия Менделеева с Евразийским континентом (по геофизическим данным) // Региональная геология и металлогения. 2018. № 74. C. 5-18].

Kashubin S.N., Petrov O.V., Rybalka A.V., Milshtein E.D, Shokalsky S.P., Verba M.L., Petrov E.O., 2017. Earth's Crust Model of the South-Okhotsk Basin by Wide-angle OBS Data. Tectonophysics 710-711,37-55. https://doi.org/10.1016/j. tecto.2016.11.021.

Kashubin S.N., Sakulina T.S., Pavlenkova N.I., Lukashin Yu.P., 2011b. Features of Wave Fields of Compressional and Shear Waves in Marine Deep Seismic Studies. Technologies of Seismic Prospecting 4, 88-102 (in Russian) [Кашубин С.Н., Сакулина Т.С., Павленкова Н.И., Лукашин Ю.П. Особенности волновых полей продольных и поперечных волн при глубинных сейсмических исследованиях на акваториях // Технологии сейсморазведки. 2011. № 4. C. 88-102].

Kostyuchenko S.L., Egorkin A.V., Solodilov L.N., 1999. Structure and Genetic Mechanisms of the Precambrian Rifts of the East-European Platform in Russia by Integrated Study of Seismic, Gravity, and Magnetic Data. Tectonophysics 313 (1-2), 9-28. https://doi.org/10.1016/S00401951(99)00187-0.

Kostyuchenko S.L., Morozov A.F., 2007. Geological and Geophysical Images of the Crust and Upper Mantle of the Territory of Russia in Maps and Models. In: Models of the Earth's Crust and Upper Mantle Based on Deep Seismic Profiling. Proceedings of the International Scientific and Practical Seminar (September 18-20, 2007). VSEGEI Publishing House, Saint Petersburg, p. 82-85 (in Russian) [Костюченко С.Л., Морозов А.Ф. Геолого-геофизические образы земной коры и верхней мантии территории России в картах и моделях // Модели земной коры и верхней 
мантии по результатам глубинного сейсмопрофилирования: Материалы Международного научно-практического семинара (18-20 сентября 2007 г.). СПб.: Изд-во ВСЕГЕИ, 2007. С. 82-85].

Kosygin Yu.A., 1975. Fundamentals of Tectonic Zoning. In: Principles of Tectonic Zoning. Vladivostok, p. 8-24 (in Russian) [Косыгин Ю.А. Основы тектонического районирования // Принципы тектонического районирования. Владивосток, 1975. С. 8-24].

Kulinich R.G., Valitov M.G., 2011. Thicknesses and Types of the Crust beneath the Sea of Japan Inferred from Marine and Satellite Gravimetric Investigations. Russian Journal of Pacific Geology 5 (6), 481-491. https://doi.org/10.1134/ S1819714011060078.

Kunin N.Ya., Goncharova N.V., Semenova G.I. et al., 1987. Mantle Surface Relief Map of Eurasia. Institute of the Physics of the Earth of the USSR Academy of Science, RSFSR Ministry of Geology, Moscow (in Russian) [Кунин Н.Я., Гончарова Н.В., Семенова Г.И. и др. Карта рельефа поверхности мантии Евразии. М.: ИФЗ АН СССР, Мингео РСФСР, 1987].

Lebedeva-Ivanova N.N., Zamansky Y.Y., Langinen A.E., Sorokin M.Y., 2006. Seismic Profiling across the Mendeleev Ridge at $82^{\circ} \mathrm{N}$ : Evidence of Continental Crust. Geophysical Journal International 165 (2), 527-544. https://doi.org/ 10.1111/j.1365-246X.2006.02859.x.

Li S., Mooney W.D., Fan J., 2006. Crustal Structure of Mainland China from Deep Seismic Sounding Data. Tectonophysics 420 (1-2), 239-252. https://doi.org/10.1016/j. tecto.2006.01.026.

Ljones F., Kuwano A., Mjelde R., Breivik A., Shimamurac H., Murai Y., Nishimura Y., 2004. Crustal Transect from the North Atlantic Knipovich Ridge to the Svalbard Margin West of Hornsund. Tectonophysics 378 (1-2), 17-41. https://doi. org/10.1016/j.tecto.2003.10.003.

Maus S., Barckhausen U., Berkenbosch H., Bournas N., Brozena J., Childers V., Dostaler F., Fairhead J.D., Finn C., von Frese R.R.B. et al., 2009. EMAG2: A 2- Arc Min Resolution Earth Magnetic Anomaly Grid Compiled from Satellite, Airborne, and Marine Magnetic Measurements. Geochemistry, Geophysics, Geosystems 10 (8). https://doi.org/10.1029/ 2009 GC002471.

Millera H.G., Singh V., 1994. Potential Field TILT - a New Concept for Location of Potential Field Sources. Journal of Applied Geophysics 32 (2-3), 213-217. https://doi.org/ 10.1016/0926-9851(94)90022-1.

Miura S., Takahashi N., Nakanishi A., Tsuru T., Kodaira S., Kaneda Y., 2005. Structural Characteristics off Miyagi Forearc Region, the Japan Trench Seismogenic Zone, Deduced from a Wide-Angle Reflection and Refraction Study. Tectonophysics 407 (3-4), 165-188. https://doi.org/10.1016/j. tecto.2005.08.001.

Mjelde R., Raum T., Kandilarov A., Murai Y., Takanami T., 2009. Crustal Structure and Evolution of the Outer Møre Margin, NE Atlantic. Tectonophysics 468 (1-4), 224-243. https://doi.org/10.1016/j.tecto.2008.06.003.

Mooney W.D., 2007. Crust and Lithospheric Structure Global Crustal Structure. In: B. Romanowicz, A. Dziewonski (Eds), Treatise on Geophysics. Vol. 1: Seismology and Structure of the Earth. Elsevier, p. 361-417. https://doi.org/10.1016/ B978-044452748-6.00011-0.

Morozov A.F., Mezhelovsky N.V., Pavlenkova N.I. (Eds), 2006. Lithospheric Structure and Dynamics of Eastern Europe. In: EUROPROBE Research Results. Vol. 2. GEOKART, GEOS, Moscow, 735 p. (in Russian) [Строение и динамика литосферы Восточной Европы // Результаты исследований по программе EUROPROBE / Ред. А.Ф. Морозов, Н.В. Межеловский, Н.И. Павленкова. М.: ГЕОКАРТ, ГЕОС, 2006. T. 2. 735 c.].

Morozov A.F., Petrov O.V., Shokalsky S.P., Kashubin S.N., Kremenetsky A.A., Shkatov M.Yu., Kaminsky V.D., Gusev E.A. et al., 2013. New Geological Data Substantiating the Continental Origin of the Area of Central Arctic Uplifts. Regional Geology and Metallogeny 53, 34-55 (in Russian) [Mopoзов А.Ф., Петров О.В., Шокальский С.П., Кашубин С.Н., Кременецкий А.А., Шкатов М.Ю., Каминский В.Д., Гусев Е.А. и др. Новые геологические данные, обосновывающие континентальную природу области Центрально-Арктических поднятий // Региональная геология и металлогения. 2013. № 53. С. 34-55].

Nakanishi A., Kurashimo E., Tatsumi Y., Yamaguchi H., Miura S., Kodaira S., Obana K., Takahashi N., Tsuru T., Kane da Y. et al., 2009. Crustal Evolution of the Southwestern Kuril Arc, Hokkaido Japan, Deduced from Seismic Velocity and Geochemical Structure. Tectonophysics 472 (1-4), 105-123. https://doi.org/10.1016/j.tecto.2008.03.003.

Pavlenkova N.I., Kashubin S.N., Gontovaya L.I., Pavlenkova G.A., 2018. Deep Structure and Geodynamics of the Sea of Okhotsk Region. Regional Geology and Metallogeny 78, 70-82 (in Russian) [Павленкова Н.И., Кашубин С.Н., Гонтовая Л.И., Павленкова Г.А. Глубинное строение и геодинамика Охотоморского региона // Региональная геология и металлогения. 2018. № 76. С. 70-82].

Pavlenkova N.I., Kashubin S.N., Pavlenkova G.A., 2016. The Earth's Crust of the Deep Platform Basins in the Northern Eurasia and Their Origin. Izvestiya, Physics of the Solid Earth 52, 770-784. https://doi.org/10.1134/S10693513 16050128.

Pavlenkova N.I., Pavlenkova G.A., 2014. Structure of the Crust and Upper Mantle of Northern Eurasia from the Data of Seismic Profiling with Nuclear Explosions. GEOKART, GEOS, Moscow, 191 p. (in Russian) [Павленкова Н.И., Павленкова Г.А. Строение земной коры и верхней мантии Северной Евразии по данным сейсмического профилирования с ядерными взрывами. М.: ГЕОКАРТ, ГЕОС, 2014. 191 c.].

Pavlis N.K., Holmes S.A., Kenyon S.C., Factor J.K., 2012. The development and evaluation of the Earth Gravitational Model 2008 (EGM2008). Journal of Geophysical Research: Solid Earth 117 (B4), 1-38. https://doi.org/10.1029/ 2011JB008916.

Petrov O.V. (Ed.), 2008. GIS Atlas of Geological Maps of Russia, CIS Countries and Neighboring Countries. Scale 1:2500000. VSEGEI Publishing House, Saint Petersburg (in Russian] [ГИС-Атлас геологических карт России, стран СНГ и сопредельных государств. Масштаб 1:2500000 / Ред. О.В. Петров. СПб.: Изд-во ВСЕГЕИ, 2008]. 
Petrov O.V., Dong S., Kiselev E.A., Morozov A.F. (Eds), 2016a. International Project. Atlas of Geological Maps of Asia and Adjacent Areas. VSEGEI Publishing House, Saint Petersburg, $48 \mathrm{p}$.

Petrov O., Morozov A., Shokalsky S., Kashubin S., Artemieva I.M., Sobolev N., Petrov E., Ernst R.E., Sergeev S., Smelror M., 2016b. Crustal Structure and Tectonic Model of the Arctic Region. Earth-Science Reviews 154, 29-71. https:// doi.org/10.1016/j.earscirev.2015.11.013.

Petrov O.V., Morozov A.F., Zubova T.N., Shishkin M.A., Kashubin S.N., Shokalsky S.P., Shatov V.V., Tolmacheva T.Yu., Leonov Yu.G., Fedonkin M.A., Khanchuk A.I., 2016c. Russian Scientific School of Geological Cartography in Compiling New Generation of the State Geological Maps of the Russian Federation, Its Continental Shelf and Abyssal Oceanic Margins of Eurasia and Circumpolar Arctic. Regional Geology and Metallogeny 67, 6-18 (in Russian) [Петров O.В., Морозов А.Ф., Зубова Т.Н., Шишкин М.А., Кашубин С.Н., Шокальский С.П., Шатов В.В., Толмачева Т.Ю., Леонов Ю.Г., Федонкин М.А., Ханчук А.И. Российская научная школа геологической картографии в создании нового поколения государственных геологических карт территории Российской Федерации, ее континентального шельфа и глубоководных окраин Евразии и Циркумполярной Арктики // Региональная геология и металлогения. 2016. № 67. C. 6-18].

Poselov V.A., Avetisov G.P., Kaminsky V.D. et al., 2011. Russian Arctic Geotraverses. VNIIOkeangeologia, Saint Petersburg, 172 p. (in Russian) [Поселов В.А., Аветисов Г.П., Каминский В.Д. и др. Российские арктические геотраверсы. СПб.: ФГУП «ВНИИОкеангеология», 2011. 172 с.].

Poselov V., Butsenko V., Chernykh A., Glebovsky V., Jackson H.R., Potter D.P., Oakey G., Shimeld J., Marcussen C., 2014. The Structural Integrity of the Lomonosov Ridge with the North American and Siberian Continental Margins. In: D.B. Stone, G.E. Grikurov, J.G. Clough, G.N. Oakey, D.K. Thurston (Eds), ICAM VI: Proceedings of the International Conference on Arctic Margins VI (May 2011, Fairbanks, Alaska). VSEGEI Publishing House, Saint Petersburg, p. 233-258.

Reference Geological and Geophysical Profiles of Russia, 2013. Deep Seismic Sections along the DSS Profiles Performed from 1972 to 1995. Atlas. VSEGEI Publishing House, Saint Petersburg, 94 p. (in Russian) [Опорные геологогеофизические профили России. Глубинные сейсмические разрезы по профилям ГСЗ, отработанным в период с 1972 по 1995 год: Атлас. СПб.: ВСЕГЕИ, 2013. 94 с.]. http://www.vsegei.com/ru/info/seismic/ (Дата последнего обращения: 30.03.2021).

Roslov Yu.V., Sakoulina T.S., Pavlenkova N.I., 2009. Deep Seismic Investigations in the Barents and Kara Seas. Tectonophysics 472 (1-4), 301-308. https://doi.org/10.1016/j. tecto.2008.05.025.

Sakulina T.S., Kalenich A.P., Atakov A.I., Tihonova I.M., Krupnova N.A., Pyzhjanova T.M., 2011a. Geological Model of the Okhotsk Sea Region According to Basic Profiles 1-OM and 2DW-M. Prospect and Protection of Mineral Resources 10, 1117 (in Russian) [Сакулина Т.С., Каленич А.П., Атаков А.И.,
Тихонова И.М., Крупнова Н.А., Пыжьянова Т.М. Геологическая модель Охотоморского региона по данным опорных профилей 1-ОМ и 2-ДВ-М // Разведка и охрана недр. 2011. № 10. С. 11-17].

Sakulina T.S., Kashubin S.N., Petrov O.V., Morozov A.F., Krupnova N.A., Dergunov N.T., Razmatova A.V., Tabyrtca S.N., Kashubina T.V., Yavarova T.M., 2016. Deep Structure of the Earth's Crust and Upper Mantle of the North Chukchi Basin of the DSS Dream-Line Profile. Regional Geology and Metallogeny 68, 52-65 (in Russian) [Сакулина Т.С., Кашубин С.Н., Петров О.В., Морозов А.Ф., Крупнова Н.А., Дергунов Н.Т., Разматова А.В., Табырца С.Н., Кашубина Т.В., Яварова Т.М. Глубинное строение земной коры и верхней мантии Северо-Чукотского прогиба по профилю ГСЗ Dreamline // Региональная геология и металлогения. 2016. № 68. C. 52-65].

Sakulina T.S., Verba M.L., Kashubina T.V., Krupnova N.A., Tabyrtsa S.N., Ivanov G.I., 2011b. Complex Geological and Geophysical Researches on Profile 5-AP in the East Siberian Sea. Prospect and Protection of Mineral Resources 10, 1723 (in Russian) [Сакулина Т.С., Верба М.Л., Кашубина Т.В., Крупнова Н.А., Табырца С.Н., Иванов Г.И. Комплексные геолого-геофизические исследования на опорном профиле 5-АР в Восточно-Сибирском море // Разведка и охрана недр. 2011. № 10. С. 17-23].

Sal'nikov A.S. (Ed.), 2007. Crustal Structure of the Magadan Sector of Russia from Geological and Geophysical Data. Nauka, Novosibirsk, 173 p. (in Russian) [Структура и строение земной коры Магаданского сектора России по геологогеофизическим данным / Ред. А.С. Сальникова. Новосибирск: Наука, 2007. 173 с.].

Takahashi N., Kodaira S., Tatsumi Y., Yamashita M., Sato T., Kaiho Y., Miura S., No T., Takizawa K., Kaneda Y., 2009. Structural Variations of Arc Crusts and Rifted Margins in the Southern Izu-Ogasawara Arc-Back Arc System. Geochemistry, Geophysics, Geosystems 10 (9). https://doi.org/10. 1029/2008GC002146.

Teng J., Zhang Z., Zhang X., Wang C., Gao R., Yang B., Qiao Y., Deng Y., 2013. Investigation of the Moho Discontinuity beneath the Chinese Mainland Using Deep Seismic Sounding Profiles. Tectonophysics 609, 202-216. https://doi.org/10. 1016/j.tecto.2012.11.024.

Volvovsky B.S., Volvovsky I.S., 1988. Structures of Continents with Granite-Free Type of Crust. In: Geodynamic Research. Problems of Deep Geology of the USSR Territory. Vol. 12. Moscow, p. 169-187 (in Russian) [Вольвовский Б.С., Вольвовский И.С. Структуры континентов с «безгранитным» типом земной коры // Геодинамические исследования. Проблемы глубинной геологии территории СССР. М., 1988. Вып. 12. С. 169-187].

Voronin A.Yu., 2007. Zoning of Territories Based on Artificial Intelligence and Pattern Recognition for Natural Resources Management Problems. Brief PhD Thesis (Doctor of Technical Sciences). Moscow, 44 p. (in Russian) [Bopoнин А.Ю. Районирование территорий на основе искусственного интеллекта и распознавания образов в задачах природопользования: Автореф. дис. ... докт. тех. наук. М., 2007. 44 с.]. 
Wang Y., Mooney W.D., Yuan X., Coleman R.G., 2003. The Crustal Structure from the Altai Mountains to the Altyn Tagh Fault, Northwest China. Journal of Geophysical Research: Solid Earth 108 (B6). https://doi.org/10.1029/ 2001 jb000552.

Zhao W., Mechie J., Brown L.D., Guo J., Haines T., Hearn T., Klemperer S.L., Ma Y.S., Meissner R., Nelson K.D. et al., 2001. Crustal Structure of Central Tibet as Derived from Project INDEPTH Wide-Angle Seismic Data. Geophysical Journal International 145 (2), 486-498. https://doi.org/10.1046/j. 0956-540x.2001.01402.x.

Zolotov E.E., Kostyuchenko S.L., Rakitov V.A., 1998. Tomographic Sections of the Lithosphere of the East European Platform. In: F.P. Mitrofanov, N.V. Sharov (Eds), Seismological
Model of the Lithosphere of Northern Europe: Barents Region. Vol. 1. Publishing House of KSC RAS, Apatity, p. 71-79 (in Russian) [Золотов Е.Е., Костюченко С.Л., Ракитов В.А. Томографические разрезы литосферы Восточно-Европейской платформы // Сейсмологическая модель литосферы Северной Европы: Баренцевский регион / Ред. Ф.П. Митрофанов, Н.В. Шаров. Апатиты: Изд-во КНЦ РАН, 1998. Ч. 1. С. 71-79].

Zverev C.M., Kosminskaya I.P. (Eds), 1980. Seismic Models of the Lithosphere of the Main Geostructures of the USSR Territory. Nauka, Moscow, 84 p. (in Russian) [Сейсмические модели литосферы основных геоструктур территории СССР // Ред. С.М. Зверев, И.П. Косминская. М.: Наука, 1980. 84 с.]. 